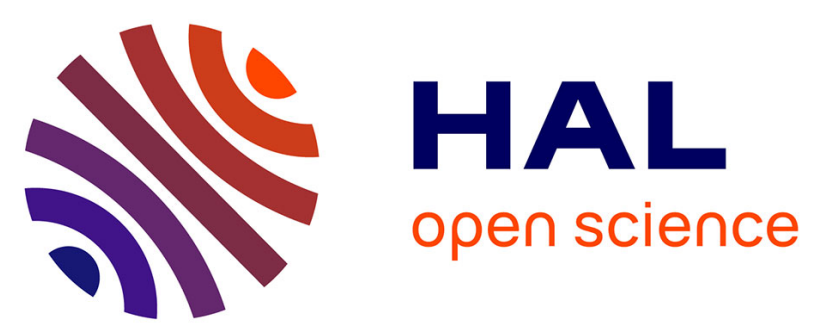

\title{
ESTIMATION OF THE EFFICIENCY OF STRUCTURAL FUNDS: A PARAMETRIC AND NON-PARAMETRIC APPROACH
}

Juan Gómez-García, María del Rocio Moreno Enguix, Juan Cándido

Gómez-Gallego

\section{To cite this version:}

Juan Gómez-García, María del Rocio Moreno Enguix, Juan Cándido Gómez-Gallego. ESTIMATION OF THE EFFICIENCY OF STRUCTURAL FUNDS: A PARAMETRIC AND NON-PARAMETRIC APPROACH. Applied Economics, 2011, pp.1. 10.1080/00036846.2011.583224 . hal-00712385

\section{HAL Id: hal-00712385 https://hal.science/hal-00712385}

Submitted on 27 Jun 2012

HAL is a multi-disciplinary open access archive for the deposit and dissemination of scientific research documents, whether they are published or not. The documents may come from teaching and research institutions in France or abroad, or from public or private research centers.
L'archive ouverte pluridisciplinaire HAL, est destinée au dépôt et à la diffusion de documents scientifiques de niveau recherche, publiés ou non, émanant des établissements d'enseignement et de recherche français ou étrangers, des laboratoires publics ou privés. 


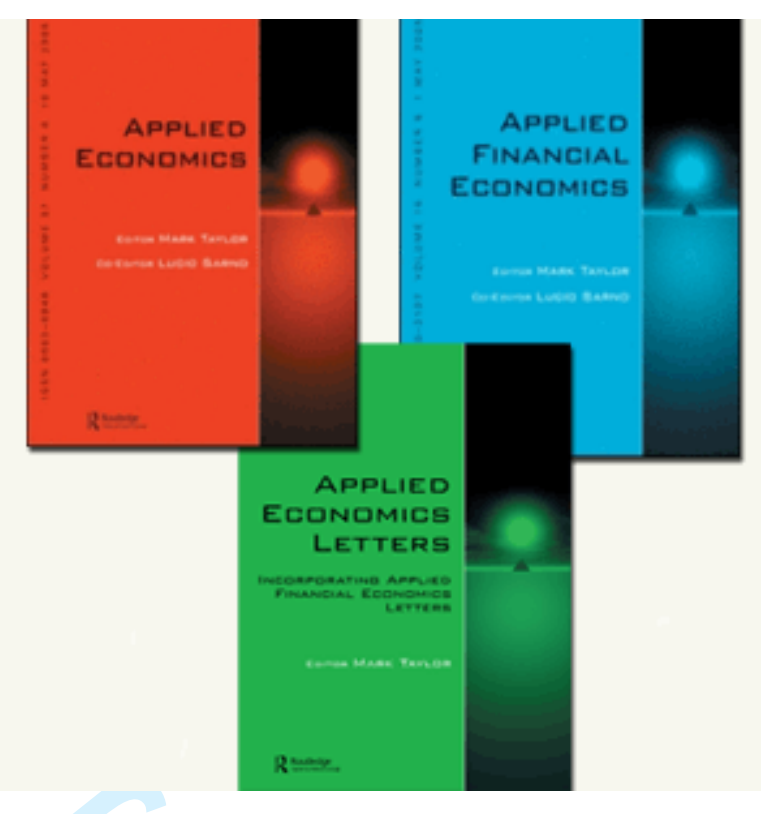

\section{ESTIMATION OF THE EFFICIENCY OF STRUCTURAL FUNDS: A PARAMETRIC AND NON-PARAMETRIC APPROACH}

\begin{tabular}{|r|l|}
\hline Journal: & Applied Economics \\
\hline Manuscript ID: & APE-2010-0024.R1 \\
\hline Journal Selection: & Applied Economics \\
\hline Date Submitted by the \\
Author: & 23-Oct-2010 \\
\hline Complete List of Authors: & $\begin{array}{l}\text { Gómez-García, Juan; Universtiy of Murcia, Metodos Cuantitativos } \\
\text { para la Economía } \\
\text { Moreno Enguix, María del Rocio; University of Murcia, Economía } \\
\text { Financiera y Contabilidad } \\
\text { Gómez-Gallego, Juan Cándido; Universidad Católica S. Antonio, } \\
\text { Economía Financiera y Contabilidad }\end{array}$ \\
\hline JEL Code: & $\begin{array}{l}\text { C14 - Semiparametric and Nonparametric Methods < C1 - } \\
\text { Econometric and Statistical Methods: General < C - Mathematical } \\
\text { and Quantitative Methods, H21 - EfficiencylOptimal Taxation < H2 - } \\
\text { Taxation, Subsidies, and Revenue < H - Public Economics, O18 - } \\
\text { Regional, Urban, and Rural Analyses < O1 - Economic Development } \\
\text { <O - Economic Development, Technological Change, and Growth, } \\
\text { H83 - Public Administration < H8 - Miscellaneous Issues < H - } \\
\text { Public Economics }\end{array}$ \\
\hline Keywords: & $\begin{array}{l}\text { Regional Policy, Structural Funds, Efficiency, DEA, Stochastic } \\
\text { Frontier }\end{array}$ \\
\hline
\end{tabular}




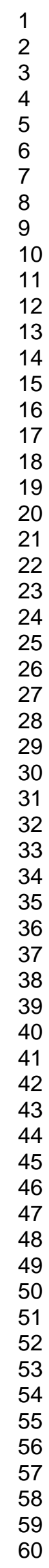

SCHOLARONE ${ }^{\text {M }}$
Manuscripts

10

12

13

14

15

16

18

19

20

22

23

25

26

27

29

32

33

34

35

36

39

40

41

42

44

45

46

47

48

50

51

52

53

54

56

57

58

60

Editorial Office, Dept of Economics, Warwick University, Coventry CV4 7AL, UK 
TABLE 1. Descriptive statistics: ERDF, ESF, EAGGF (million of euros)

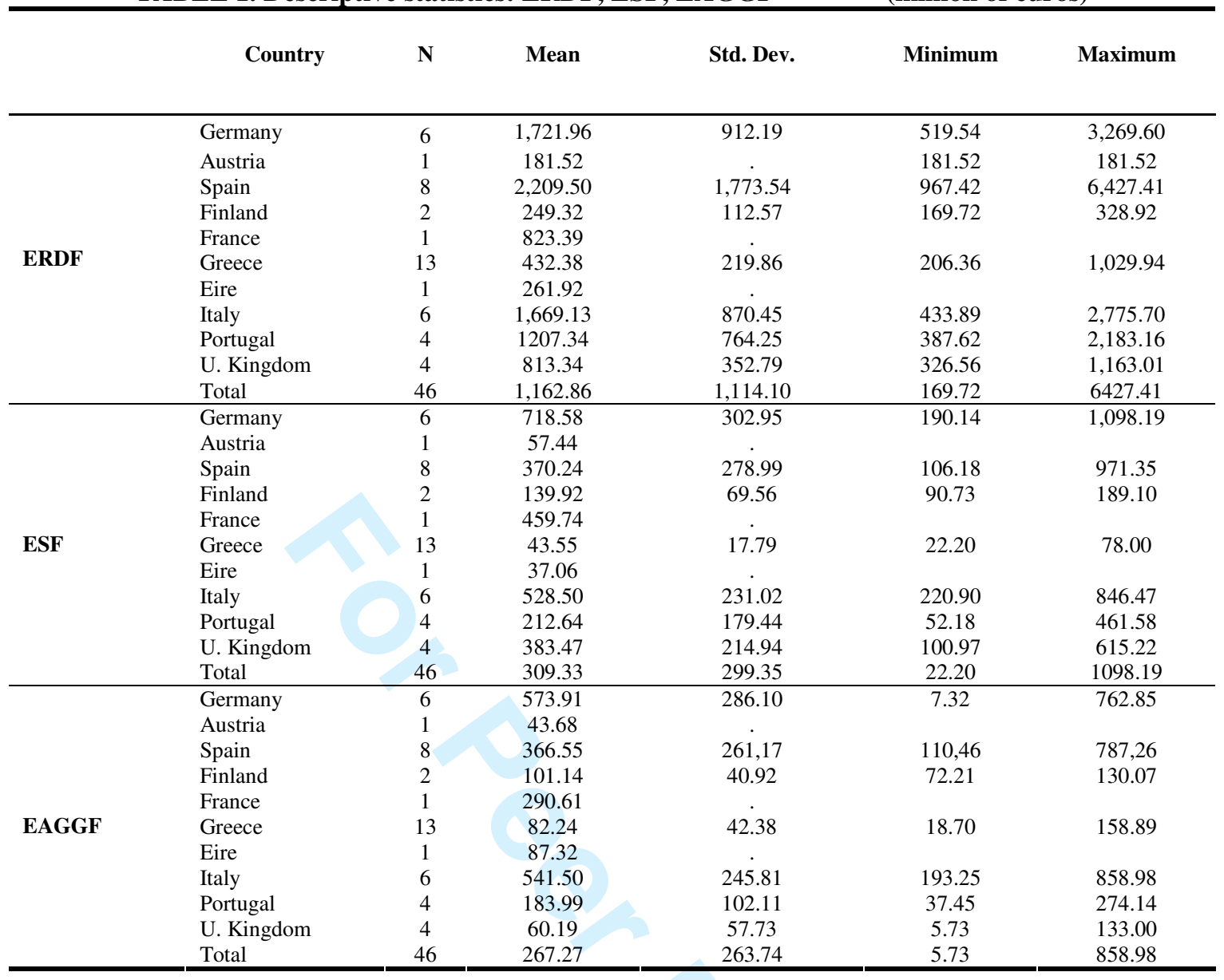

TABLE 2. Descriptive statistics: Rate of Employment and Rate of Productivity

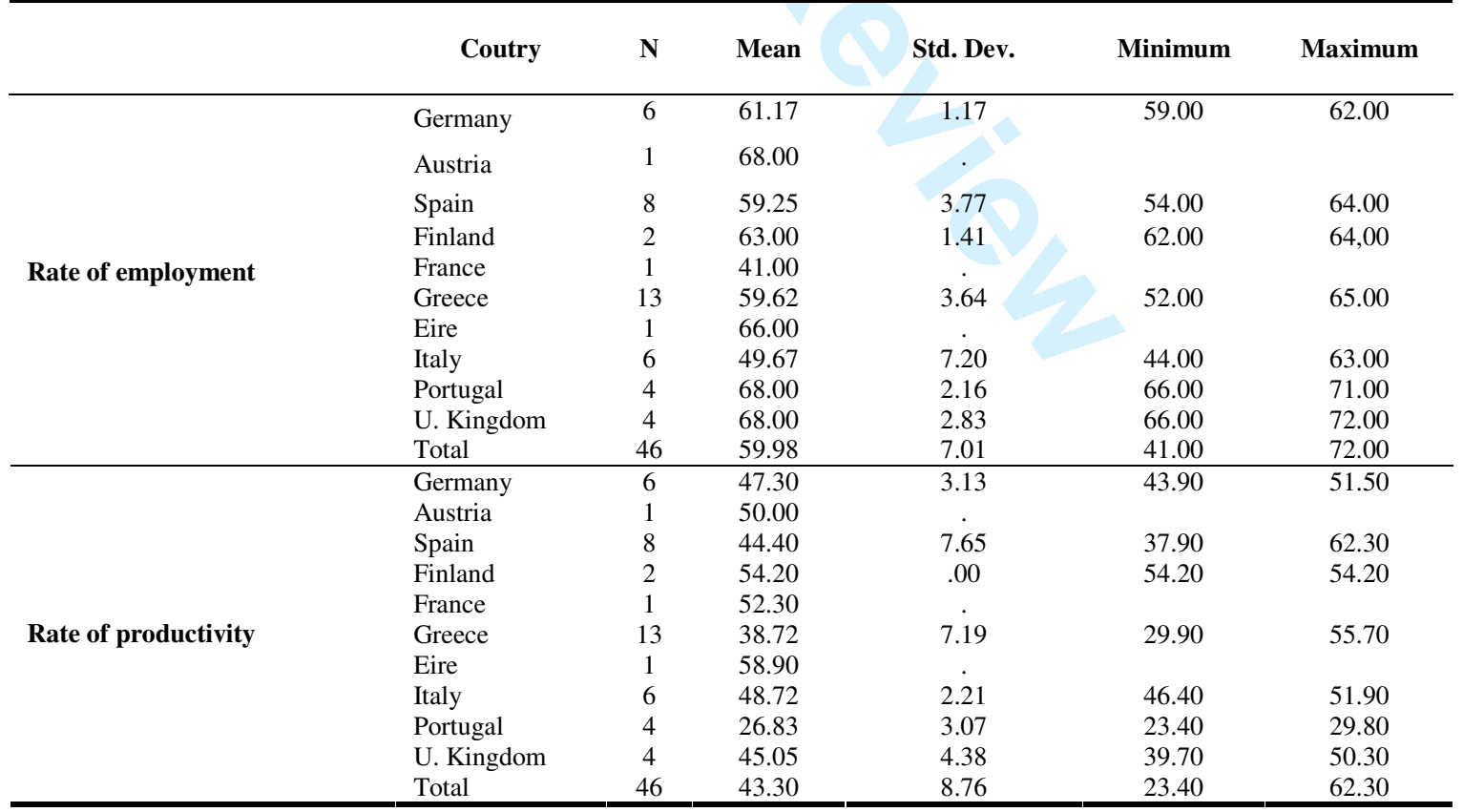


TABLE 5. Pure Technical Efficiency, Global Technical Efficiency and Scale Efficiency

\begin{tabular}{|c|c|c|c|c|c|c|c|c|c|}
\hline \multirow{2}{*}{ Region } & \multirow[b]{2}{*}{ Country } & \multicolumn{3}{|c|}{ Efficiency } & \multirow{2}{*}{ Region } & \multirow[b]{2}{*}{ Country } & \multicolumn{3}{|c|}{ Efficiency } \\
\hline & & PTE & GTE & SE & & & PTE & GTE & SE \\
\hline Alentejo & Portugal & 92.68 & 23.99 & 25.88 & Stelä Soumi & Finland & 100 & 100 & 100 \\
\hline Algarve & Portugal & 100 & 71,21 & 71,21 & Dikity Ellada & Greece & 86.16 & 60.63 & 70.37 \\
\hline Andalucia & Spain & 81.37 & 3.20 & 3.93 & Galicia & Spain & 87.63 & 7.70 & 8.79 \\
\hline Attiki & Greece & 100 & 100 & 100 & Lille de la $\mathbf{R}$. & France & 84.87 & 21.01 & 24.76 \\
\hline Asturias & Spain & 83.03 & 24.78 & 29.84 & Ionia Nisia & Greece & 100 & 100 & 100 \\
\hline Basilicata & Italy & 93.55 & 38.50 & 41.15 & Kentriki Makedonia & Greece & 82.56 & 28.74 & 34.81 \\
\hline Berlín & Germany & 100 & 100 & 100 & Anatoliki Makedonia T. & Greece & 82.22 & 81.00 & 98.52 \\
\hline Border, M.W. & Ireland & 100 & 100 & 100 & Dytiki Makedonia & Greece & 85.85 & 35.71 & 41.60 \\
\hline Branderburg & Germany & 90.55 & 9.46 & 10.45 & Mecklenbourg-V & Germany & 88.11 & 12.91 & 14.65 \\
\hline Burgenland & Austria & 100 & 100 & 100 & Merseyside & U. Kingdom & 100 & 100 & 100 \\
\hline Valencia & Spain & 90.17 & 11.11 & 12.32 & Murcia & Spain & 100 & 33.41 & 33.41 \\
\hline Calabria & Italy & 75.73 & 13.40 & 17.69 & Wales R. V. & U. Kingdom & 95.51 & 19.79 & 20.72 \\
\hline Campania & Italy & 75.74 & 6.61 & 8.73 & Peloponnisos & Greece & 100 & 100 & 100 \\
\hline Islas Canarias & Spain & 85.07 & 14.74 & 17.33 & Puglia & Italy & 78.35 & 9.54 & 12.18 \\
\hline Castilla-M. & Spain & 88.57 & 12.53 & 14.15 & Centro & Portugal & 98.84 & 16.15 & 16.34 \\
\hline Sterea Ellada & Greece & 89.74 & 56.96 & 63.47 & Norte & Portugal & 91.17 & 11.40 & 12.50 \\
\hline Cornwall S. & U.Kingdom & 100 & 59.37 & 59.37 & Sardegna & Italy & 81.58 & 14.66 & 17.97 \\
\hline Kriti & Greece & 96.05 & 56.9 & 58.50 & Sachsen & Germany & 87.91 & 5.89 & 6.70 \\
\hline Notio Aigaio & Greece & 86.81 & 65.61 & 75.58 & Sachsen Anhalt & Germany & 89.01 & 8.13 & 9.13 \\
\hline Voreio Aigaio & Greece & 100 & 86.48 & 86.48 & Sicilia & Italy & 78.51 & 6.94 & 8.84 \\
\hline Iperios & Greece & 86.09 & 65.36 & 75.92 & Thessalia & Greece & 90.29 & 53.61 & 59.38 \\
\hline Extremadura & Spain & 80.00 & 11.12 & 13.90 & Thüringen & Germany & 90.04 & 10.60 & 11.77 \\
\hline Pohjois Soumi & Finland & 93.31 & 52.79 & 56.57 & Yorkshire-H. & U. Kingdom & 100 & 57.52 & 57.52 \\
\hline
\end{tabular}

TABLE 3. Descriptive statistics: Contribution of Agriculture to GDP

TABLE 4. Correlation matrix amongst the inputs, outputs, PTE, GTE and SE

\begin{tabular}{|c|c|c|c|c|c|c|c|c|}
\hline & PTE & GTE & SE & ERDF & ESF & EAGGF & $\begin{array}{c}\text { Rate of } \\
\text { employment }\end{array}$ & $\begin{array}{c}\text { Rate of } \\
\text { productivity }\end{array}$ \\
\hline PTE & 1 & $.670(* *)$ & $.613(* *)$ & $-.459(* *)$ & $-.417(* *)$ & $-.600(* *)$ & $.821(* *)$ & .122 \\
\hline GTE & & 1 & $.995(* *)$ & $-.648(* *)$ & $-.679(* *)$ & $-.753(* *)$ & $.367(*)$ & .128 \\
\hline SE & & & 1 & $-.667(* *)$ & $-.704(* *)$ & $-.763(* *)$ & $.320(*)$ & .094 \\
\hline ERDF & & & & 1 & $.793(* *)$ & $.756(* *)$ & -.272 & .005 \\
\hline ESF & & & & & 1 & $.839(* *)$ & -.287 & .193 \\
\hline EAGGF & & & & & & 1 & $-.429(* *)$ & .125 \\
\hline Rate of employment & & & & & & & 1 & -.210 \\
\hline
\end{tabular}

ANOVA: ** significance $\alpha=0,05 ; *$ significance $\alpha=0,1$

\begin{tabular}{llccccc}
\hline \multicolumn{1}{c}{ Country } & N & Mean & Std. Dev. & Minimum & Maximum \\
& Germany & 6 & 1.70 & 1.25 & .00 & 3.80 \\
& Austria & 1 & 4.70 &. & 4.70 & 4.70 \\
& Spain & 8 & 5.99 & 4.15 & 1.40 & 12.40 \\
& Finland & 2 & 1.50 & .00 & 1.50 & 1.50 \\
Contribution Agric GDPP & France & 1 & 1.80 &. & 3.92 & 8.00 \\
& Greece & 13 & 4.86 & 1.46 & & \\
& Eire & 1 & 3.60 &. & 2.80 & 6.50 \\
& Italy & 6 & 4.40 & 1.26 & .40 & 13.70 \\
& Portugal & 4 & 6.35 & 5.03 & .10 & 2.80 \\
& U. Kingdom & 4 & 1.15 & 1.24 & & 13.70 \\
\hline
\end{tabular}


TABLE 6. Estimation of Mean of PTE, GTE and SE in the regions depending on the country of origin

TABLE 7. Estimation of Mean of PTE, GTE and SE in the regions depending on the geographical situation of country of origin

\begin{tabular}{|c|c|c|c|c|c|c|}
\hline & \multirow{2}{*}{$\begin{array}{l}\text { Geographical } \\
\text { situation }\end{array}$} & \multirow{2}{*}{$\mathbf{N}$} & \multirow{2}{*}{ Mean } & \multirow{2}{*}{$\begin{array}{c}\text { Standard } \\
\text { Error }\end{array}$} & \multicolumn{2}{|c|}{ Mean C. I. 95\% } \\
\hline & & & & & L. inferior & L. superior \\
\hline \multirow{2}{*}{ PTE } & Southern_Europe & 32 & 88.32 & 1.52 & 85.34 & 91.30 \\
\hline & Total & 46 & 90.03 & 1.42 & 87.24 & 92.82 \\
\hline GTE & Southern_Europe & 32 & 42.13 & 9.38 & 23.73 & 60.53 \\
\hline \multirow{3}{*}{ SE } & Southern_Europe & 32 & 46.04 & 9.91 & 26.60 & 65.49 \\
\hline & Northern_Europe & 14 & 52.65 & 13.30 & 50.69 & 78.73 \\
\hline & Total & 46 & 45.34 & 7.46 & 30.70 & 59.98 \\
\hline
\end{tabular}


TABLE 9. Estimations relating to inefficient function

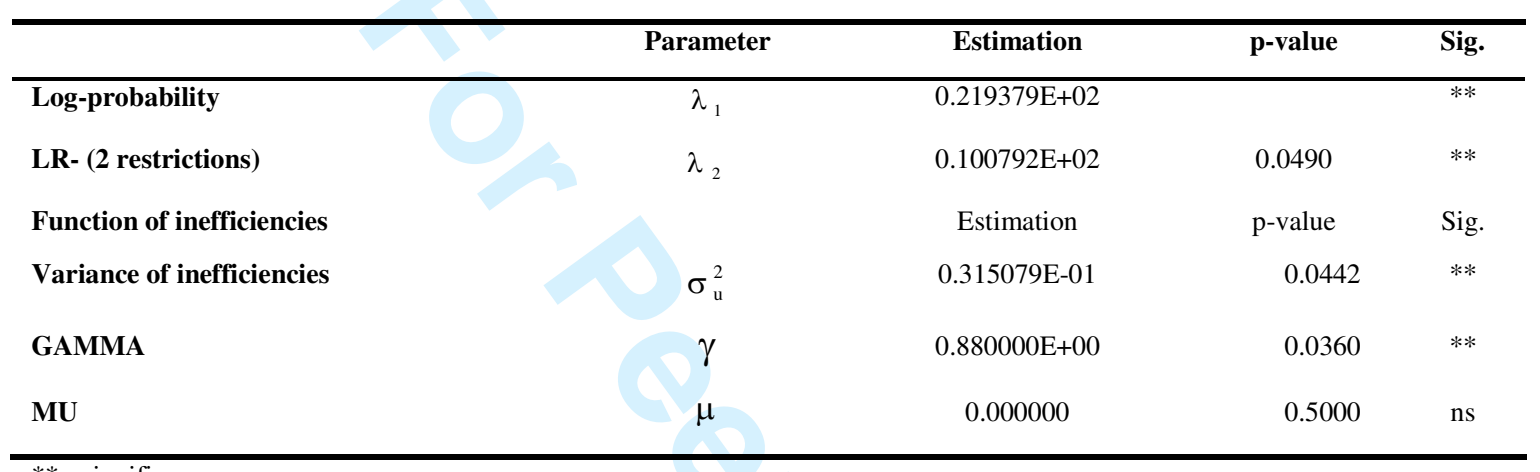

$* *=$ significance $\alpha=0,05$

TABLE 10. Estimation of Frontier Stochastic Model

\begin{tabular}{llllr}
\hline Variable & Parameter & Coeficient & Standar-Error & t-ratio \\
\hline Constant & $\beta_{0}$ & $0.415526 \mathrm{E}+01$ & $0.437976 \mathrm{E}+00$ & $0.948741 \mathrm{E}+01$ \\
ERDF & $\beta_{\text {FEDER }}$ & $-0.124803 \mathrm{E}-08$ & $0.999691 \mathrm{E}-10$ & $-0.124842 \mathrm{E}+02$ \\
ESF & $\beta_{\text {FSE }}$ & $0.868733 \mathrm{E}-01$ & $0.116898 \mathrm{E}-01$ & $0.743152 \mathrm{E}+01$ \\
EAGGF & $\beta_{\text {FEOGA }}$ & $0.138026 \mathrm{E}-09$ & $0.830536 \mathrm{E}-10$ & $0.166189 \mathrm{E}+01$ \\
ESF* EAGGF & $\beta_{\text {FSE } * \text { FEOGA }}$ & $-0.617744 \mathrm{E}-01$ & $0.309486 \mathrm{E}-01$ & $-0.199602 \mathrm{E}+01$ \\
Elasticity ERDF & $\mathrm{E}_{\text {FEDER }}$ & $-1.248030 \mathrm{E}-09$ & & $0.048^{* * *}$ \\
Elasticity ESF & $\mathrm{E}_{\text {FSE }}$ & $-2.215493 \mathrm{E}-01$ & & $0.023 * *$ \\
Elasticity EAGGF & $\mathrm{E}_{\text {FEOGA }}$ & $-3.171663 \mathrm{E}-01$ & & \\
\hline
\end{tabular}

$* *$ significance $\alpha=0,05$. 
TABLE 11. Tecnichal Efficiency of European Objective 1 Regions. 2000-2006

\begin{tabular}{|c|c|c|c|c|c|c|c|}
\hline Region & Country & Efficiency & Inefficiency & Region & Country & Efficiency & Inefficiency \\
\hline Alentejo & Portugal & 92.80 & 7.20 & Stelä Soumi & Finland & 89.07 & 10.93 \\
\hline Algarve & Portugal & 90.92 & 9.08 & Dikity Ellada & Greece & 76.20 & 23.80 \\
\hline Andalucia & Spain & 84.02 & 15.98 & Galicia & Spain & 78.96 & 21.04 \\
\hline Attiki & Greece & 83.31 & 16.69 & Lille de la $\mathbf{R}$. & France & 73.16 & 26.84 \\
\hline Asturias & Spain & 75.56 & 24.44 & Ionia Nisia & Greece & 83.49 & 16.51 \\
\hline Basilicata & Italy & 84.48 & 15.52 & Kentriki Makedonia & Greece & 80.98 & 19.02 \\
\hline Berlín & Germany & 73.88 & 26.12 & Anatoliki Makedonia T. & Greece & 84.21 & 15.79 \\
\hline Border, M.W. & Ireland & 86.69 & 13.31 & Dytiki Makedonia & Greece & 88.10 & 11.90 \\
\hline Branderburg & Germany & 87.67 & 12.33 & Mecklenbourg-V & Germany & 87.13 & 12.87 \\
\hline Burgenland & Austria & 87.27 & 12.73 & Merseyside & U. Kingdom & 89.38 & 10.62 \\
\hline Valencia & Spain & 94.67 & 5.33 & Murcia & Spain & 86.13 & 13.87 \\
\hline Calabria & Italy & 77.47 & 22.53 & Wales R. V. & U. Kingdom & 92.36 & 7.64 \\
\hline Campania & Italy & 77.32 & 22.68 & Peloponnisos & Greece & 84.96 & 15.04 \\
\hline Islas Canarias & Spain & 86.91 & 13.09 & Puglia & Italy & 89.19 & 10.81 \\
\hline Castilla-M. & Spain & 88.16 & 11.84 & Centro & Portugal & 96.41 & 3.59 \\
\hline Sterea Ellada & Greece & 82.27 & 17.73 & Norte & Portugal & 94.82 & 5.18 \\
\hline Cornwall S. & U.Kingdom & 92.44 & 7.56 & Sardegna & Italy & 75.82 & 24.18 \\
\hline Kriti & Greece & 90.74 & 9.26 & Sachsen & Germany & 87.00 & 13.00 \\
\hline Notio Aigaio & Greece & 75.51 & 24.49 & Sachsen Anhalt & Germany & 86.69 & 13.31 \\
\hline Voreio Aigaio & Greece & 80.62 & 19.38 & Sicilia & Italy & 85.57 & 14.43 \\
\hline Iperios & Greece & 74.61 & 25.39 & Thessalia & Greece & 85.12 & 14.88 \\
\hline Extremadura & Spain & 39.52 & 60.48 & Thüringen & Germany & 89.11 & 10.89 \\
\hline Pohjois Soumi & Finland & 86.81 & 13.19 & Yorkshire-H. & U. Kingdom & 90.85 & 9.15 \\
\hline
\end{tabular}

TABLE 12. Estimation of parameter of the efficient distributions depending on the country of origin

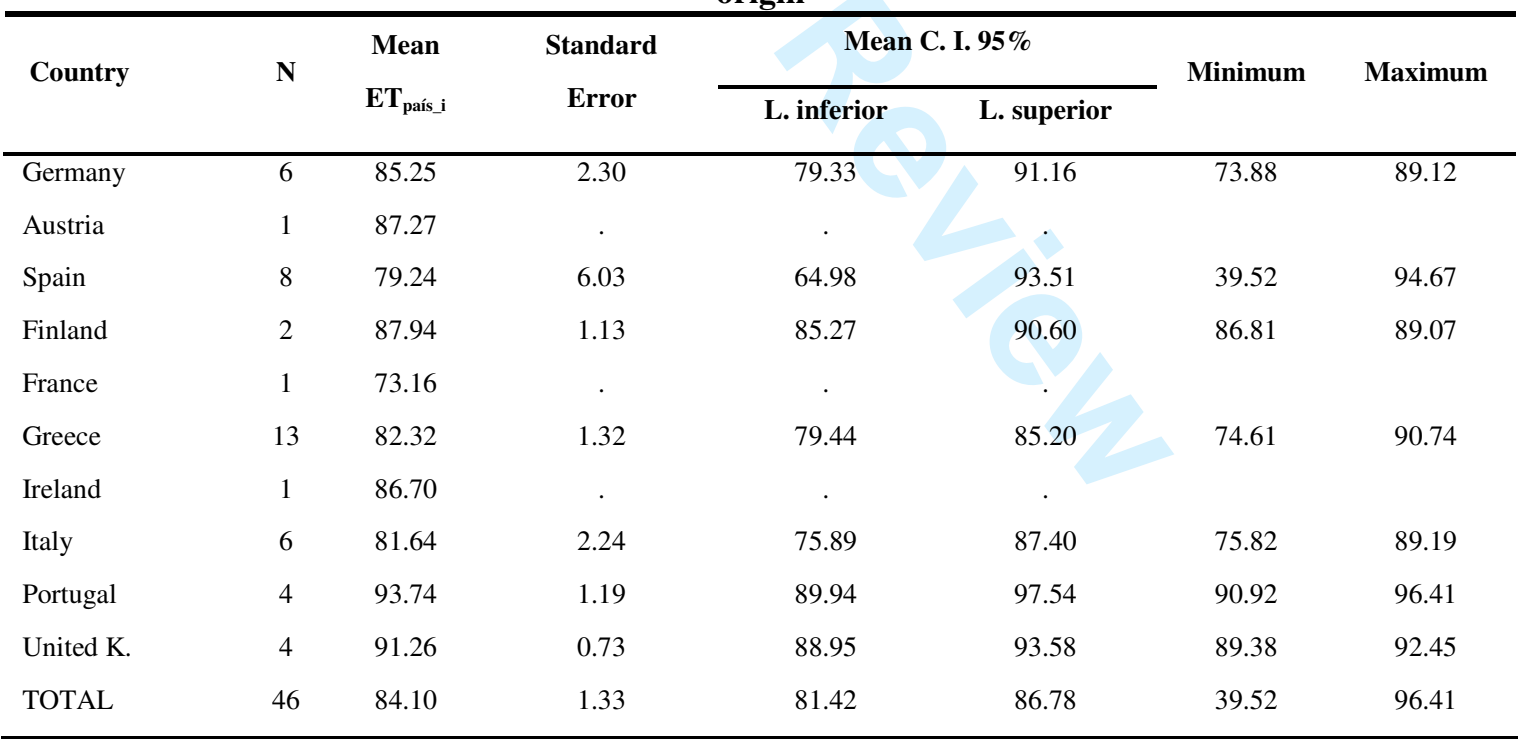


TABLE 13. Estimation of parameter of inefficient distribution depending on the country of origin

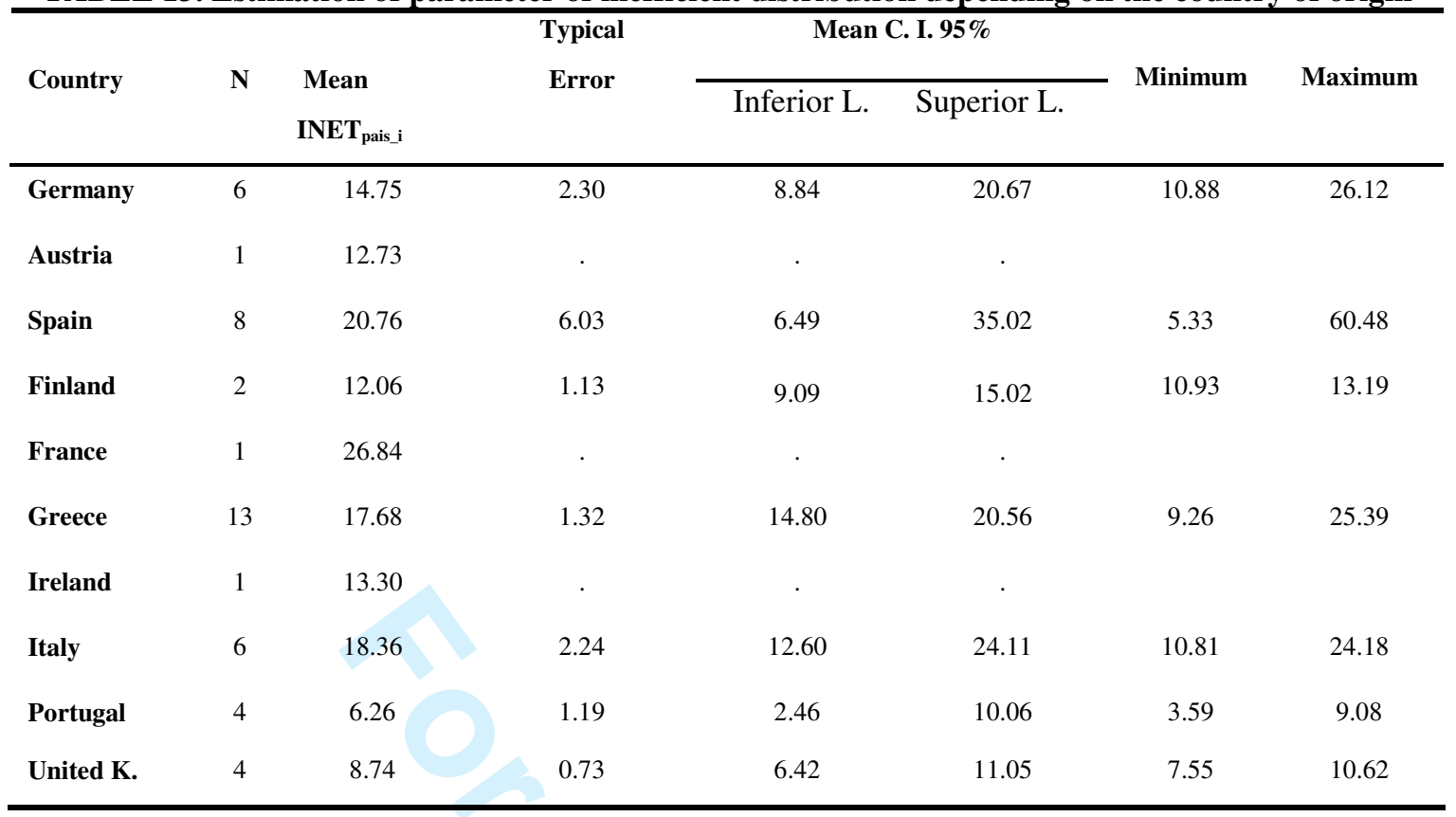

TABLE 14. Descriptive statistical of the efficient values depending on the geographical situation of country of origin

\begin{tabular}{|c|c|c|c|c|c|c|c|}
\hline & \multirow[b]{2}{*}{$\mathbf{N}$} & \multirow[b]{2}{*}{ Mean } & \multirow{2}{*}{$\begin{array}{l}\text { Typical } \\
\text { Error }\end{array}$} & \multicolumn{2}{|c|}{ Mean C. I. 95\% } & \multirow[b]{2}{*}{ Minimum } & \multirow[b]{2}{*}{ Maximum } \\
\hline & & & & Inferior L. & Superior L. & & \\
\hline North_Europe & 14 & 87.60 & 1.19 & 85.04 & 90.16 & 73.88 & 92.45 \\
\hline South_Europe & 32 & 82.56 & 1.79 & 78.92 & 86.20 & 39.52 & 96.41 \\
\hline Total & 46 & 84.10 & 1.33 & 81.42 & 86.78 & 39.52 & 96.41 \\
\hline
\end{tabular}

TABLE 15. Estimation of parameter of the efficient distributions for each country depending on

\begin{tabular}{|c|c|c|c|c|c|c|c|}
\hline & \multirow[t]{2}{*}{$\mathbf{N}$} & \multirow[t]{2}{*}{ Mean } & \multirow{2}{*}{$\begin{array}{l}\text { Typical } \\
\text { Error }\end{array}$} & \multicolumn{2}{|c|}{ Mean C. I. 95\% } & \multirow{2}{*}{ Minimum } & \multirow{2}{*}{ Maximum } \\
\hline & & & & Inferior $L$. & Superior L. & & \\
\hline -C_AGR_GDP & 23 & 86.39 & 0.88 & 84.57 & 88.22 & 75.56 & 92.80 \\
\hline +C_AGR_GDP & 23 & 81.55 & 2.55 & 76.25 & 86.85 & 39.52 & 96.41 \\
\hline Total & 46 & 84.03 & 1.36 & 81.29 & 86.76 & 39.52 & 96.41 \\
\hline
\end{tabular}




\section{INTRODUCTION}

One of the main Objectives of the European Union is the promotion of economic and social convergence of all the Member States and their regions. The European Union devotes an important part of its resources to financing regional development projects, through its Structural Funds the European Regional Development Fund (ERDF), the European Social Fund (ESF), the Guidance Section of the European Agricultural Guidance and Guarantee Fund (EAGGF-Guidance) and the Financial Instrument for Fisheries Guidance (FIFG) in lesser developed areas of the Union. Distribution of these Funds is made on the basis of regions' economic and social situation with respect to the European mean. Regions are classified according to certain geographical indicators which are shown in NUTS 1, NUT 2 and NUTS 3 (up to the period of aid 2000-2006 regions were also classified as Objective 1, Objective 2 and Objective 3 according to their economic and social situation).

Regional policies seek to enable regions to increase their competitiveness and development, and as such a priority Objective of activities financed by Structural Funds is higher employment, higher productivity and economic activity.

How efficiently the regions apply the funds is a fundamental issue for the development and continuity of regional policies, and especially so in the context of the current economic crisis and the growing number of regions with low levels of development that the incorporation of new countries into the European Union has supposed. Such circumstances have forced the European Union to make huge economic efforts to maintain and increase the resources for the Funds, and so it is vital for European authorities to know how efficiently these are being applied.

Despite there being difficulties in determining this efficiency, it was in the 1970s that Moore and Rhodes (1973) first evaluated the impact that regional policies had had on employment in regions of the United Kingdom. Since then several authors have followed on and have developed an array of techniques and methodologies to determine how efficiently the Structural Funds are being applied and to what extent the regions are achieving convergence.

European authorities have likewise recognized the importance of ascertaining the efficiency with which the funds are being used. The European Commission in its Third Report on Cohesion (2004) laid out the importance of evaluating the results of regional policies carried out as an initial requisite for the preparation of the following period of financing. The Commission also holds regular conferences aimed at evaluating the impact of regional policies. The last of these was in Budapest 2003, where the importance of evaluating efficiency was recognized in order to guarantee the proper development of the regions and their future continuity. Various techniques and methodologies were also put forward for the evaluation, following and impact of programmes carried out with the Structural Funds.

We therefore consider that determining the efficiency of European regional policies is an issue of high relevance, and it is the main aim of this study. Currently, the trend in efficiency studies revolves around the application of non-parametric and parametric models. Among the non-parametric techniques, they enable us to consider a multiplicity of outputs and inputs in the analysis, and thus make less severe demands on the whole and the frontier of production Pedraja and Salinas (1995). Furthermore, as pointed out by Varian (1990), in practice, the need to impose parametric structures upon the data does not exist when there are non-parametric assumptions. DEA is the most accepted estimator because of the fact that its methodology is superior to estimates which use ordinary minimum squares, and it is consistent with 
the definition of the production function Blackorby and Russel (1989). The studies which compare the different frontier methodologies used conclude that DEA and parametric frontier approximations are almost concordant in their most important aspects Ferrier and Lovell (1990) and Lovell and Wood (1992). The nature of activities in the public sector has led to the use of DEA techniques when multiple outputs are produced Ahn et al. (1989), which offers advantages such as: allowing the overall analysis of each service; not requiring prior definition of a production function that requires the creation of a mythical unit with which to perform the comparison Shang and Sueyoshi (1995); providing information on the best practices for each inefficient unit; allowing the inclusion of exogenous variables as uncontrollable inputs; and not requiring the assumption of fulfilment of statistical hypotheses, such as normality, multicolinearity or heteroscedasticity.

The parametrical methodology Stochastic Frontiers is rationale behind the choice lies mainly in the advantage it offers over Data E... Analysis (DEA), in that it allows inefficiencies and other stochastic perturbations which influence measures of efficiency to be distinguished, so avoiding overestimations of inefficiencies [Bauer et al., (1998); Yildirim and Philippatos (2007)].

Therefore, we have considered it appropriate to use the available information to apply a mathematical technique known as Data Envelopment Analysis, DEA, and Stochastic Frontier models which these allows us to calculate the technical efficiency and inefficiency of the Structural Funds applied in the Objective 1 regions for the period 2000-2006.

The paper is organized as follows. Section 2 reviews previous literature on evaluation of efficiency of European regional policies. Section 3 provides a detailed description of the research objective and methodology. Section 4 describes the samples of European regions and input/output used in the research. Besides, it presents the variables that are going to be related to efficiency indicators. Section 5 examines relationships among variables and results that we have obtained with the two methodologies. Finally, section 6 summarizes and conclusions.

\section{PREVIOUS STUDIES}

There have been several studies to determine how efficient European regional policies are and their influence on the degree of economic and social convergence attained by less developed areas. We can highlight the studies by Krugman and Obstfeld (1997); Dornbush (2000) and Boldrin and Canova (2001), which have reviewed the situation of European regional policy and the consequences it has had on the affected regions; Christodoulakis and Kalyvitis (1998) captured the impact of Structural Funds on the Greek economy; Jouve and Negrier (1998) studied the influence on Structural Funds in the intergovernmental relations in France; Grabbe and Hughes (1998) analyzed the reform of Structural Funds and the effect on principles of solidarity and cohesion; Boland (1999) studied the influence on efficiency of governance structure of Merseyside, region Objective 1; Musyck amd Reid (2007) studied the influence of Structural Funds in the innovations in regions Objective 2 during 2000-2006; Churski (2008) analyzed the efficiency and influence of Structural Funds on changes of regional economic in Poland.

The results of these studies are not unanimous, while some studies such as Krugman and Obstfeld (1997), Dornbush (2000), Boldrin and Canova (2001), Boland (1999) do not find a very significant impact of the Structural Funds in the development and growth of the regions; others studies such as Christodoulakis 
and Kalyvitis (1998) and Churski (2008) find a significant impact of the Structural Funds on the European regional policy objectives.

Other studies have used various methods to determine the efficiency of the application of the Structural Funds: Moore and Rodhes (1973) developed a model which determines the accumulative effects of these policies in the United Kingdom; The CGE model was used by Bourguignon et al. (1992) to analyse Greek regions; Bradley (1997) determined the impact of the Structural and Cohesion Funds by applying the HERMIN econometric model; The European Commission (1997) developed an econometric model called QUEST, which seeks to ascertain the efficiency of the resources employed in these political regions; María-Dolores and García (2001) found the incidence of the Structural Funds on Spanish regions by using two, complementary methodologies, conventional calculations for convergence and selectivity models; Beutel (2002) applied input-output analyses using matrices developed by EUROSTAT; Treyz and Treyz (2003) used the REMI model for their study; Quindós et al. (2003) analysed the efficiency of the funds invested by the Union in R+D activities; Rodriguez-Pose and Fratesi (2004) studies the impact of Structural Funds in Objective 1 regions using cross-sectional and panel data analyses; Beugelsdijk and Eijffinger (2005) in their study about the effectiveness of Structural Funds; Delgado and Álvarez (2005) determined the technical efficiency in European Union countries by application of data envelopment analysis, DEA, and the translogarithmic production function, a stochastic frontier model; Armstrong and Wells (2006) determined the efficiency of Structural Funds in South of Yorkshire with evaluation methods; Martin and Tyler (2006) studies the impact of Structural Funds on Objective 1 regions using the same model of Moore and Rodhes (1973).

More recent studies have sought to determine the efficiency of Objective 1 regions over the latest period of financing, 2000-2006, by applying various techniques, e.g. Puigcerver (2007) who determined the impact of regional policies in Objective 1 regions through the use of temporal series; Kutan and Yigit (2007) used DEA to determine the impact of the Structural Funds on convergence and growth of productivity in less developed European countries; Dall'erba and Le Gallo (2007) and Dall'erba and Le Gallo (2008) determined the impact of Structural Funds on the convergence progress between European regions applying a econometric methods; Espostí and Bussoletti (2008) investigate the impact of the Structural Funds on Objective 1 regions using panel data econometric models; Lima and Cardenete (2008) analyze the impact of the ERDF in the regions of the South of Spain applying the Applied General Equilibrium Model (AGEM); Gripaos et al. (2008) examined the impact of Structural Funds in Objective 1 regions and reviewed other empirical studies.

Although these studies have used different techniques such as parametric or non-parametric models, the results obtained show that, some studies find some type of impact of the Structural Funds on employment and growth such as Moore and Rodhes (1973), Martin and Tyler (2006), Rodriguez-Pose and Fratesi (2004), Beugelsdijk and Eijffinger (2005), Beutel (2002), Treyz and Treyz (2003), María-Dolores and García (2001), Kutan and Yigit (2007), Puigcerver (2007) and Lima and Cardenete (2008). However, Dall'erba and Le Gallo (2007) and Dall'erba and Le Gallo (2008), Gripaos et al. (2008) and Espostí and Bussoletti (2008) determined that the impact of the Structual Funds depends on other variables and geographical situation. 
Given the large volume of resources employed in policies financed by the Structural Funds and the importance of the Objectives pursued, this paper seeks to perform an analysis of the efficiency of the application of these resources by those regions classified as Objective 1 over the period 2000-2006. In the first place we are going to identify which are the most efficient regions by calculating both the level of efficiency according to the results obtained from the resources used (Pure Technical Efficiency, PTE) and the degree of efficiency according to their optimum production capacity (Scale Efficiency, SE).. We will use the Data Envelopment Analysis, DEA. This methodology is widely used to determine efficiency in the use of services by public entities [Benito et al. (2010), Nolan et al. (2001), Salinas-Jiménez (2003) and Afonso et al. (2010)], and today it has been applied by authors like Prior (1990), Taskim and Zaim (1997), Pedraja et al. (1999), Maudos et al. (1998), Maudos et al. (2000a), Maudos et al. (2000b), Quindós et al. (2003), , Delgado and Álvarez (2005), Maudos and Gumbau-Albert (2006) and Kutan and Yigit (2007) to determine the degree of convergence and the efficiency of European funds applied to increase productivity and employment in both the regional and the national sphere.

Furthermore, we will use the Stochastic Frontier methodology, which is widely used to determine efficiency in the regional sphere. This methodology has been applied by authors like Prior (1990), Domazlicky and Weber (1997), Maudos et al. (2000a), Maudos et al. (2000c), Puig-Junoy (2001) and Picazo-Tadeo and Prior (2009).

Other studies such as Kempkes and Pohl (2010) have used both methodologíes to determine the efficiency of public entities.

Finally, we will analyse the extent to which certain factors have repercussions on the efficiency.

\section{EVALUATION OF EFFICIENCY: METHODOLOGY}

The two central concepts of this section are production frontier and efficiency (technical). The former refers to the maximum theoretical output possible from a combination of inputs and the technology. The second is defined by Farrell (1957) as the capacity of an entity to achieve the maximum output from a given set of inputs. Thus, evaluating the technical efficiency (or inefficiency) of a set of entities means first estimating the production frontier, since this is not known in practice.

Estimation methods to construct the production frontier can be classified according to whether it is necessary to specify a functional form which relates inputs with outputs in parametric or non parametric methods. Statistical or non statistical methods can be also be used to estimate the frontier which, in the final instance, can be specified as stochastic (random) or determinist. This study uses the non parametric method known as Data Envelopment Analysis and parametric model Stochastic Frontier

\section{DEA methodology}

DEA does not require any hypothesis to be established as to the functional form of the relation between inputs and outputs, or any inefficiency distribution. It is also able to consider situations of multiple inputs and outputs, expressed as different units. These are the advantages of DEA that have led to its widespread use $^{1}$.

\footnotetext{
${ }^{1}$ A detailed literature base on DEA can be consulted at en www.banxia.com/frontier/bbliography.html. Analysis of the efficiency of a set of entities with DEA involves having software capablle of solving the problem addressed. Free software includes that written by Coelli (1996): deap and EMS, Scheel (2000): EMS. These can be downloaded from: www.uq.edu.au/economics/cepa/soltware.htm and www.wiso.unidortmund.de/lsfg/or/scheel/ems. Another, commercially available
} 
DEA is an extension of the work by Farrell $^{2}$ (1957) and was developed by Rhodes (1978) in his PhD thesis. In the same year, the article "Measuring the Efficiency of Decision Making Units" was published in the European Journal of Operational Research by Charnes et al. (1978). There the formalization of the first DEA model, popularly known as DEA-CCR model, was presented.

Within the hypothesis that the DEA-CCR model supposes is the convexity and the scale constant returns. The relaxing of the latter, by allowing the production technology to exhibit scaled variable returns comes from Banker et al. (1984), and gives rise to the so called DEA-BBC model. Both provide radial (proportional) efficiency measures - oriented input or output. In this last sense, it has to borne in mind that, according to Charnes et al. (1981), efficiency can be characterized in relation to two basic orientations output oriented model and Input oriented models. In our study we applied the DEA-CCR and DEA-BCC outputs oriented.

DEA-CCR output oriented model ${ }^{3}$

The CCR model can be expressed as a matrix by:

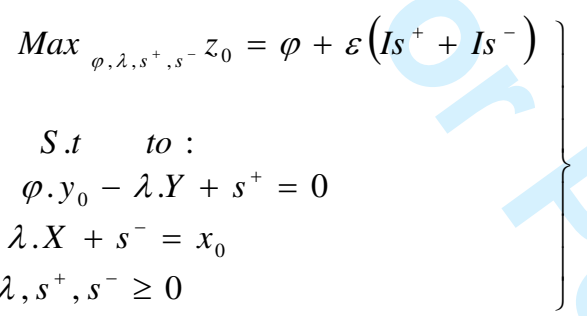

where $\mathrm{Y}$ is a matrix of outputs of order $(\mathrm{sxn}), \mathrm{X}$ is a matrix of inputs of order $(\mathrm{mxn}), \mathrm{y}_{0} \mathrm{y} \mathrm{x}_{0}$ represent the output and input vector, respectively, of the entity being evaluated, $\lambda$ is the vector (nx1) of weights or intensities, $s^{+}$is output slack variable and $s^{-}$is input slack variable.

The solution of the model can be solved in double step, and it is the optimum solution $\left(\varphi^{*}, s^{+^{*}}, s^{-^{*}}\right)$ then $\varphi^{*} \geq 1$. So the more $\varphi^{*}$ will be more inefficient the evaluated unit will be. The unit will be classified as technically efficient if and only if $\varphi^{*}=1$ and all the slacks are zero $\left(s^{+^{*}}=0, s^{-^{*}}=0\right)$. Otherwise the unit is classified as inefficient and it is possible to obtain from the $\lambda_{\mathrm{j}}^{*}$ values a combination of entities which functions better than that evaluated. The output technical efficient of the unit will be $1 / \varphi^{*}$.

The DEA-CCR models formulated above suppose that the technology satisfies among other properties, constant returns to scale, and provides a (global) measure of technical efficiency (GTE). Banker, et al. (1984) relax this supposition and allow the technology to present scale variable returns. The operativity of this supposition translates into the addition of the so called convexity constraint $\overrightarrow{1} \lambda=1$ in the model expressed in (2), so eliminating the influence of the of the production scale. The measure of efficiency

program is professional Frontier Analyst (www.banxia.com); DEA Solver Pro (www.saitech-inc.com), DEA Frontier (Zhu (2002)) and Warwic-DEA.

${ }^{2}$ The main developments of the estimation methods of productive efficiency were put forward by Farrell (1957) in the Discussion section of his paper. Forsund (1999) addresses the original ideas therein and establishes connections with the determinist parametric approach, the stochastic approach and DEA.

${ }^{3}$ See Coelli et al. (1998) 
thus obtained is a pure technical efficiency measure (PTE) technical efficiency measures that are without any scale effect Thanassoulis (2001).

The technical efficient will be $1 / \varphi^{*}$. The entity evaluated will be classified as efficient (PTE), if and only if $\varphi^{*}=1$ and The slack variables are all null

The typology of the results which can be obtained from applying the DEA-BCC model to evaluate the efficiency of a set of entities is similar to that given by the CCR model, only now it is possible to decompose the technical efficiency and the pure and scale technical efficiency, and also to determine the type of return that each particular entity operates with locally.

$$
\mathrm{ETG}=\mathrm{ETP} * \mathrm{EE}
$$

\subsection{Analysis of stability of results. Bootstrap analysis and confidence intervals}

As expressed above, one limitation of DEA analysis is the dependence on the result obtained from the data available. The efficiency values obtained with this technique are relative measures which are obtained by comparing the input-output combinations of the units evaluated with those entities situated at the efficient frontier and, in consequence, changes in the efficient combinations will affect the efficiency measures of all the units evaluated. Thus, any anomaly or imprecision in the data will have notable repercussions on the results.

One way of solving this drawback is to apply the Bootstrap method developed by Efron (1979), which has become a powerful tool in statistical analysis. Although it is an intensive calculation method, the use of computers has simplified and popularized its use.

The bootstrap method is based on the direct calculation of the estimator variance of the population parameter which one wishes to estimate and considers the sample as if it were the total population and uses the Montecarlo method to obtain replicas of the sample. For a more detailed study of these techniques, which have grown importantly since the pioneer study by Efron (1979), see Efron and Tibshirani (1993), Davison and Hinkley (1997) or Simar and Wilson (2000).

\section{Stochastic Frontier methodology}

Stochastic Frontier A estimates the production frontier of productive units, DMUs, through a stochastic function and the subsequent measurement of the technical efficiency, TE, by using the Farell ${ }^{4}$ indexes (1957), and takes into consideration the deviations in production of each DMU with respect to the estimated production frontier.

Aigner, et al. (1977) and, at the same time, Meeusen and Van Den Broeck (1977) were the first to propose the estimation of a stochastic frontier production to assess the technical efficiency (or inefficiency) of an entity by means of the following expression:

$$
\begin{gathered}
\mathrm{y}_{\mathrm{i}}=\mathrm{f}\left(\mathrm{x}_{\mathrm{i}}, \beta\right)+\varepsilon_{\mathrm{i}} \quad \mathrm{i}=1,2, \ldots \mathrm{N} \\
\varepsilon_{\mathrm{i}}=\mathrm{v}_{\mathrm{i}}-\mathrm{u}_{\mathrm{i}}
\end{gathered}
$$

\footnotetext{
${ }^{4}$ Alternatively in the studies Kopp (1981), Russell (1985) and Zieschang (1984) indexes are proposed which do not require efficiency to be measured radially.
} 
where $\mathrm{N}$ is the number of entities considered, $\mathrm{y}_{\mathrm{i}}$ is the output logarithm, $\mathrm{x}_{\mathrm{i}}$ is a row vector input, expressed in logarithms, $\beta$ is a parameter vector which needs to be estimated, $f(-)$ is the production technology ${ }^{5}$, and the term $\varepsilon_{\mathrm{i}}$ is a compound error defined by:

A symmetric perturbation, denoted by $\mathrm{v}_{\mathrm{i}}$, which covers the impact of effects which are not controlled by the entity under study. This concept may conclude possible errors in measurement, observation or other factors like bad weather, strikes, etc. It is supposed that the $\mathrm{v}_{\mathrm{i}}$ are identically and independently distributed with normal distributions of mean zero and variance $\sigma_{\mathrm{v}}^{2}$, i.e. $\mathrm{N}\left(0, \sigma_{\mathrm{v}}^{2}\right)$.

A non negative, asymmetric and time invariant error component, $u_{i}$, known as the Technical Inefficiency Effect. In the original model by Aigner, et al. (1977), technical inefficiency is considered to be distributed according to a semi-normal (or halfnormal) $\left(\|_{N}\left(0, \sigma_{u}^{2}\right)\right)$, since output can only be decreased below the frontier, although it is usual to find different distributional cases for this technical inefficiency, among which are noteworthy: the Meeusen and Van Den Broeck (1977) exponential and Aigner, et al. (1977), the truncated normal, Stevenson (1980) or Gamma Greene (1990).

Just as the production frontier function has been defined in expression (1), so the frontier output

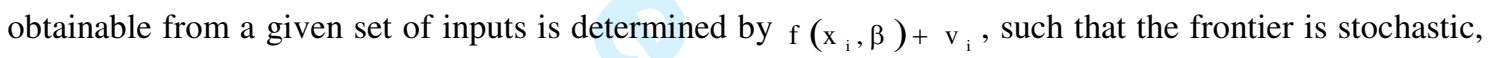
since variable $v_{i}$ is random. Note that $v_{i}$, unlike $u_{i}$, is not constrained and can take values greater, less than, or equal to zero.

On the other hand, the term $\mathrm{u}_{\mathrm{i}}$ can be considered as an efficiency index of the entity such that the technically inefficient units will be those which present positive values, i.e.,

$$
\mathrm{u}_{\mathrm{i}}=\left[\mathrm{f}\left(\mathrm{x}_{\mathrm{i}} ; \beta\right)+\mathrm{v}_{\mathrm{i}}\right]-\mathrm{y}_{\mathrm{i}}>0
$$

In other words, a unit is technically inefficient if the observed output $\left(\mathrm{y}_{\mathrm{i}}\right)$ is situated below the frontier output. If this is the case, term $\mathrm{u}_{\mathrm{i}}$ will include the amount, in absolute terms, of the output necessary for the entity to reach the frontier. In relative terms, the technical efficiency of an entity $\mathrm{i}\left(\mathrm{ET}_{\mathrm{i}}\right)$ can be expressed as a quotient between its output and the maximum output attainable:

$$
\mathrm{ET}_{\mathrm{i}}=\frac{\mathrm{y}_{\mathrm{i}}}{\left[\mathrm{f}\left(\mathrm{x}_{\mathrm{i}} ; \beta\right)+\mathrm{v}_{\mathrm{i}}\right]}
$$

or if the model to be estimated is expressed in logarithms:

$$
\mathrm{ET}_{\mathrm{i}}=\exp \left(-\mathrm{u}_{\mathrm{i}}\right)
$$

And given that ${ }_{\mathrm{u}_{\mathrm{i}}} \geq 0$, then $_{0} \leq \mathrm{ET}_{\mathrm{i}} \leq 1$.

Clearly, if the technical efficiency of a DMU is equal to the unity, the entity is efficient and technical inefficiency would be zero. Estimation by maximum likelihood ${ }^{6}$ of the model given in (1) allows only one efficiency measure to be obtained for each of the DMUs of the sampled analysed - the mean efficiency -

\footnotetext{
${ }^{5}$ This can be expressed by a production function of the type, for example, Cobb-Douglas or Translog.

${ }^{6}$ The model can also be estimated by corrected least squares (COLS) Richmond, (1974). For a detailed review of the various methods of estimation of the stochastic frontier function, see Pastor (1995).
} 
since the variable $u_{i}$ is unobservable. Only the difference $\left(v_{i}-u_{i}\right)$ is observable. Coelli et al. (1998), obtain the expected inefficiency expression for the semi-normal distribution case ${ }^{7}$ :

$$
\mathrm{E}\left(\mathrm{u}_{\mathrm{i}} / \varepsilon_{\mathrm{i}}\right)=\frac{\sigma \lambda}{\left(1+\lambda^{2}\right)}\left[\frac{\mathrm{f}\left(\varepsilon_{\mathrm{i}} \lambda / \sigma\right)}{\mathrm{F}\left(-\varepsilon_{\mathrm{i}} \lambda / \sigma\right)}-\frac{\varepsilon_{\mathrm{i}} \lambda}{\sigma}\right]
$$

where $\mathrm{F}$ and $\mathrm{f}$ are the standard normal distribution and the standard normal density function respectively. $E[u / \varepsilon]$ is an unbiased but $u_{i}$ inconsistent estimator (Greene, 1993). Jondrow et al. (1982) showed that the variability quotient (standard deviation, $\sigma$ ) of $\mathrm{u}$ and $\mathrm{v}$ can be used to measure the relative inefficiency of the entities, where $\lambda=\sigma_{u} / \sigma_{v}$ is a measure of the amount of variation due to the inefficiency with respect to the variation due to noise in the sample and $\sigma^{2}=\sigma_{u}^{2}+\sigma_{v}^{2}$. Thus, the technical efficiency of each DMU will be given by:

$$
\mathrm{ET}_{\mathrm{i}}=\exp \left(-\mathrm{E}\left(\mathrm{u}_{\mathrm{i}} / \varepsilon_{\mathrm{i}}\right)\right)
$$

In accordance with the above, an analysis of efficiency based on parametric techniques requires selecting an appropriate functional form for the production function. The most frequently applied functions are the Cobb-Douglas, which imposes constant scale returns, the translog and the Fourier-flexible, the most flexible functional form, third order approach of the production function and most complex specification. The choice of functional form is made on the basis of the application of the single tail probability test ratio $\left(\mathrm{LR}^{)}{ }^{8}\right.$. The $\mathrm{LR}$ statistic is distributed as a Chi-square whose number of degrees of freedom is equal to the number of constraints and is calculated according to the expression:

$$
L R=-2\left\{\ln \left[L\left(H_{0}\right)\right]-\ln \left[L\left(H_{1}\right)\right]\right\}
$$

where the null hypothesis $\mathrm{H}_{0}$ corresponds to the Cobb-Douglass functional form and the alternative hypothesis $H_{1}$, with the translog specification. The critical region of the $\alpha$ size test is defined by $L R_{\text {exp }}>\chi_{\text {restriccio nes } ; \alpha}^{2}$.

The LR test is also applied to contrast the form of the distribution of inefficiency probability.

\section{SAMPLE AND DEFINITION OF THE VARIABLES}

The sample considered is made up of 46 regions which belong to ten European countries whose regions have been classified as Objective 1 for the period 2000-2006 and receive resources from the Structural Funds during the period 2000-2006. The distribution of the regions according to membership of countries is: Germany (6), Austria (1), Spain (8), Finland (2), France (1), Greece (13), Eire (1), Italy (6), Portugal (4) and United Kingdom (4). The sample was obtained from information provided by the European Union in its portal for regional politics for regions classified as Objective 1 for the period 2000-2006.

The choice made for our study of the Objective 1 regions was based mainly on the important volume of resources that these receive from the Structural Funds - more than two thirds of the total amount assigned to the Structural Funds - , and to the greater homogeneity among the regions selected, since they are all in

\footnotetext{
${ }^{7}$ See Green (1993) for the $\mathrm{E}\left(\mathrm{u}_{\mathrm{i}} / \varepsilon_{\mathrm{i}}\right)$ expressions for the exponential and gamma distributions.

8 According to Coelli (1996), this test should be applied when maximum likelihood estimation is used because, in this case, the test is of the right size.
} 
a similar state of economic and social development. Hence, the results on the how efficiently the funds are used will be more reliable.

When choosing inputs and outputs, the objectives of the support have been considered, as have earlier studies by Moore and Rhodes (1973), Farë et al. (1994), Taskim and Zaim (1997), Maudos et al. (2000a), Boldrin and Canova (2001), Puig-Junoy (2001), Beutel (2002), Rodríguez-Pose and Fratesi (2004), Gardiner et al. (2005), Martin and Tayler (2006), Puigcerver (2007), Dall'erba and Le Gallo (2007) and Esposti and Bussoletti (2008).

Inputs are the resources received by each of the selected regions for the period 2000-2006 from three Structural Funds: ERDF, ESF and EAGGF. As for the fourth structural fund, FIFG, we have considered it better not to include it in this study, since its sphere of action is limited to coastal areas with fishing activity, which suppose only a small number of the regions analysed and could lead to a decrease in the reliability of the results. The inputs were obtained from information provided by the European Union in its portal for regional politics for regions classified as Objective 1 for the period 2000-2006.

Outputs considered were "rate of employment" and "rate of productivity" for the period 2000-2006, since both reflect the main objectives that the European Union pursues in its regional policy, in particular through the activities financed by the Structural Funds. These variables have been used by Farë et al. (1994), Taskim and Zaim (1997), Maudos et al. (1999), Maudos et al. (2000a), Maudos et al. (2000c), Boldrin and Canova (2001), and Delgado and Álvarez (2005). The outputs were obtained from information provided by Eurostat for the period 2000-2006. Other authors, Beugelsdijk and Eijffinger (2005) and Ederveen et al. (2006), considered as output the regional GDP, although this paper analyzes the fulfilment of the European regional objectives, employment and productivity, given that if the regions achieve these objectives, their GDP will have been increased.

Other variables considered here with the aim of explaining the efficiency measures in detail are the effect of country, the contribution of agriculture and the geographical location of the countries to which the regions analysed belong. These variables were used by Boldrin and Canova (2001).

Outputs and other variables used for the elaboration of our work have been downloaded from the Eurostat web page.

Tables 1, 2 and 3 below show descriptive information about the distributions of the selected variables: inputs, outputs and others.

(Insert Tables 1, 2 and 3)

\section{RESULTS}

\subsection{Results with DEA methodology}

First we obtained the Pearson correlations between the measures of Efficiency, (Pure Technical Efficiency, Global Technical Efficiency and Scale Efficiency), the variables considered as inputs (ERDF, ESF and EAGGF funds), those considered as outputs (Rate of Employment and Rate of Productivity) and other indicators considered in the production process. Table 4 shows the results and indicates the cases of non null correlation and significance level.

Note that the correlation coefficients have the expected signs; level of employment correlates with the three measures of efficiency. The highest correlation is PTE $(0,821)$, while GTE and SE are 0,367 and 
0,320, respectively. This result coincides with that of Martin and Tyler (2006) and Dall'erba and Le Gallo (2007); the level of productivity does not appear as significantly correlated with the efficiency measures, which coincides with the findings of Boldrin and Canova (2001) and Kutan and Yigit (2007), although not with those of Cappelen et al. (2003). PTE, GTE and SE correlate with the three Fund types (ERDF, ESF and EAGGF). In all three cases, the correlation coefficients are higher with SE than with PTE.

(Insert Table 4)

Table 5 gives the values of the coefficients of Pure Technical Efficiency, Global Technical Efficiency and Scale Efficiency obtained from the application of the DEA method to the data gleaned from the sample of the European regions studied here.

\section{(Insert Table 5)}

Eight regions operate on the optimum scale and they do so in an optimum way: Attiki (Greece), Berlin (Germany), Border, M. W. (Eire), Burgenland (Austria), Pohjois Soumi (Finland), Ionia Nisia (Greece) Merseyside (United Kingdom) and Peloponnisios (Greece). The regions which manage the resources received efficiently, notwithstanding the scale of operations are the following thirteen: Algarve (Portugal), Attiki (Greece), Berlin (Germany), Border, Midland et W. (Eire), Burgenland (Austria), Cornwall S. island (United Kingdom), Voreio Aigaio (Greece), Pohjois Soumi (Finland), Ionia Nisia (Greece), Merseyside (United Kingdom), Murcia (Spain), Peloponnisios (Greece), and Yorkshire and Humber (United Kingdom).

If we analyse the regions of the countries with highest number of Objective 1 regions, we can observe that, of the eight Spanish regions included in the study only Murcia operates efficiently, since it obtains a PTE coefficient of 100. However, it obtains a level of inefficiency because of the scale, which is above sixty-six percent $(66.59 \%)$, which is translated into the corresponding overall technical inefficiency. The most extreme case is Andalucia, whose Scale efficiency coefficient is $3.93 \%$, which signifies over ninetysix percent inefficiency for not operating on an optimum scale. However, four Greek regions have a PTE coefficient of 100, and the level of GTE and SE is higher than the Spanish regions. Therefore, the Greek regions are less inefficient in relation of their optimum scale of production.

This result indicates that the Objective 1 regions have to improve the management of received Structural Funds to increase the level of efficiency and the results in their rate of employment and productivity. Furthermore, most of the regions do not operate on an optimum scale, and it is necessary to adapt the amount of received Structural Funds with the requirements to achieve the European Structural Policy objectives and the production capacity of these regions.

\subsubsection{Comparative analysis of the measures of efficiency on the basis of different factors}

This section looks at whether the influence of certain characteristics of the regions determines different behaviours in terms of measures of efficiency. It takes as reference the studies by Raymon and García (1994), García-Milá and Marimón (1999) Martín and Tyler (2006). The following categorized variables are considered: country, group of the European Union and contribution of agriculture to the GDP of the region. 


\section{Effect of country}

Application of the Bootstrap technique returns punctual estimations and with confidence intervals of $95 \%$ of the sample means for each sub-sample of the regions according to the country to which they belong. Table 6 offers the results of the estimations for each type of efficiency: PTE, GTE and SE.

In the case of PTE, there is evidence from the data to reject equality between the mean efficiencies of all the countries. In particular, only the countries that are not efficient are considered $(\mathrm{PTE}<100)$ it can be observed that for a $5 \%$ level of significance the mean efficiency of the regions in the United Kingdom differs significantly and is higher than those of Germany (8\%), Spain (12\%), Greece (7,6\%) and Italy $(18,3 \%)$, a result which is in line with the findings of Delgado and Álvarez (2005). But, when all the countries are considered, it can be observed that the regions of Austria and Eire differ significantly and are higher than those of Germany (10\%), Spain (24\%), Greece (9\%) and Italy (20\%). The situation of the France is special, because the region analyzed is an overseas region and it has a different characteristic from the rest of the regions analyzed. It can also be observed that the mean GTE of Italy is significantly lower ran that of Germany (10\%), Finland, (28\%); Greece (53\%), Portugal (15\%) and United Kingdom, $(43 \%)$. These results coincide with those of Canova and Marcet (1995), but not with those of Beugelsdijk and Eijffinger (2005) and Crespo-Cuaresma et al. (2001).

As for SE, the cases of Spain and Italy stand out. The eight Spanish regions give a mean inefficiency level, due to the scale of operations, of $83.47 \%$, and there is a significant difference with the cases of Finland, Greece and the United Kingdom. The results for the six Italian regions show a mean inefficiency of $85 \%$, which differs significantly from the level of scale inefficiency of Finland, Greece and the United Kingdom. The results highlight the inefficiency of the Objective 1 regions in the use of Structural Funds, so efficiency could be increased by adjusting the scale of the operations. This result coincides with that obtained by Delgado and Álvarez (2005).

The results show that the countries to which regions belong are not determined on the efficiency of the Objective 1 regions in the management of Structural Funds. So the German regions or Italian regions are less efficient than Portuguese regions or Greek regions. However, Germany or Italy are better economic situation than Portugal or Greece.

(Insert Table 6)

\section{Effect of geographical location}

This section analyses the influence of the factor we have called geographical location, which classifies the regions according to whether they belong to a northern or southern European country, accepting that there are some cases in which the assignation could be debatable. Southern European countries include France, Greece, Italy, Portugal and Spain, while Austria, Eire, Finland, Germany and United Kingdom make up the northern European ones. The results of the mean efficiency estimations are shown in table 7.

It can be seen from table 7 that for the PTE case there is a significant difference between the mean values of each group. Regions coded as northern European are almost $6 \%$ more efficient than those in southern Europe. As regards GTE and SE the hypothesis of equality of mean values is not rejected. These results are in line with those of Delgado and Álvarez (2005).

These results show that the Southern countries which received more resources from European regional policy are less efficient in the management of the Structural Funds. 


\section{Effect of the Contribution of Agriculture}

This section looks at the influence of the factor we call Cont_Agric_GDP, which is defined as the percentage that the contribution of agriculture accounts for in the regional GDP corresponding to the period 2000-2006. The variable is categorized into two classes. The first sub-sample is made up by those regions where agriculture accounts for less than $4.3 \%$. The second takes in the regions where it is over $4.3 \%$.

The results of the mean estimation are given in table 8. Confidence intervals point to the existence of significant differences between two groups (in the cases of GTE and SE). The direction of the differences establishes a higher level of PTE for the group of regions in which agriculture accounts for a lower percentage. Therefore, the regions with a higher level of economic development (less contribution of agriculture to GDP) are more efficient than the agricultural regions, and are the regions that have received less Structural Funds. The results are in agreement with the findings of Maudos et al. (2000b) and Delgado and Álvarez (2003) in their study of Spanish regions.

\section{(Insert Table 8)}

\subsection{Result with Stochastic Frontier methodology}

The Battese and Coelli (1992 and 1995) models have been used in this study. These allow the measures of technical efficiency to be estimated and the determinants of technical inefficiency of a productive unit to be analysed in terms of a set of explanatory variables which are beyond its control.

Here, in the first place, a general production function of trans-logarithmic type is formulated and a normal truncated distribution for inefficiencies is supposed. The estimation of the model is performed with the Frontier 4.1 program, giving the following results: the estimated coefficients of the production function, its standard errors and the respective t-ratios. Variance in the inefficiencies term, standard error and the tratio are estimated. The LR statistic is also obtained, which allows the significance of the inefficiencies to be contrasted. Finally, the efficiency coefficients are obtained for each region and the mean efficiency and its variance are estimated.

In the first place, the functional form of the production function has been identified with the attention focused on the Cobb_Douglas and Translog models. After applying the LR probability test t-ratio, the model finally adopted is the transcendental logarithmic one. The function chosen is the most flexible one for adaptation to any type of productive technology, with no need to impose any a priori constraints on scale returns, unlike the Cobb-Douglas function, which is the most commonly chosen function in the studies by Prior et al. (2002) and Balaguer et al. (2007) in the municipal sphere; Gumbau and Maudos (2002) in the industrial sphere; Gumbau and Maudos (2006) and Cantos et al. (2005), in their regional analysis. The translogarithmic function allows existence of both complementary relations and substitution ones between the productive factors considered in the model. The function has been used in studies by Gumbau (2000), Delgado and Álvarez (2005) and Maudos et al. (2003).

Thus, the function that represents the production of the regions managing European funds takes the following expression: 
$\ln \mathrm{Y}_{\mathrm{i}}=\beta_{0}+\sum_{\mathrm{j}=1}^{3} \beta_{\mathrm{j}} \ln \mathrm{X}_{\mathrm{ji}}+\sum_{\mathrm{j}=1}^{3} \sum_{\mathrm{h}=1}^{3} \beta_{\mathrm{jh}}\left(\ln \mathrm{X}_{\mathrm{ji}}\right)\left(\ln \mathrm{X}_{\mathrm{hi}}\right)+\mathrm{V}_{\mathrm{it}}-\mathrm{U}_{\mathrm{it}}$

$i=1,2, \ldots, 46 \quad$ regions

Where $\mathrm{Y}_{\mathrm{i}}$ is the product, (Employment, Productivity) of region $\mathrm{i}$ and $\mathrm{X}_{\mathrm{i}}$ is a vector which refers to the inputs considered ( $\mathrm{j}, \mathrm{h}=\mathrm{ERDF}, \mathrm{ESF}, \mathrm{EAGGF})$ of region $\mathrm{i}$.

Technical progress is incorporated through $\beta_{0}, V_{i}$ is the random error and $U_{i}$ represents the inefficiency term.

Table 9 presents the earlier results which justify the later modelling. The null hypothesis which states that each region is operating at the frontier of technical efficiency has been contrasted and inefficiencies are therefore zero. The null hypothesis with a p-value level equal to 0.036 , less than $5 \%$, is rejected. It is, therefore, accepted that $\gamma$ is, significantly, different to zero, which indicates that inefficiency forms part of the production function.

As regards the distribution of the $u_{i}$ inefficiencies, the null hypothesis has been shown to establish that the distribution is a half-normal, with a resulting p-value of 0.5000 , so the null hypothesis is accepted.

\section{(Insert Table 9)}

Table 10 presents the results obtained in the estimation of the function of the frontier production, which is selected on the basis of the results in the contrasts of the hypotheses performed.

\section{(Insert Table 10)}

Given the above results, we can extract information about the relations between productive factors and the corresponding elasticities. In the first place, the values obtained point to the existence of complementary relations between ERDF the funds and the aggregate made up by the ESF and EAGGF funds. Furthermore, the estimated coefficients show that decreasing returns are obtained for each factor. Once the elasticities have been calculated, it is confirmed that the factor is constant for the ERDF (1.248030E-09). ESF and EAGGF inputs have reciprocal dependence and the elasticity of each factor has been calculated at the mean value of the other, obtaining negative values for both cases (table 10).

Finally, table 11 gives the values of coefficients of efficiency obtained from the application of the Stochastic Frontier method to the data gleaned from the sample of the European regions studied here. All the results emphasize the value of inefficiency of the Spanish region of Extremadura (60.48\%), and other regions like Lille Reunion, East Berlin and Asturias with a level of inefficiency of nearly 25\%, much lower than the level of the above Spanish region.

The study determines those regions with a greater level of efficiency, although none achieve the maximum level of efficiency. Among the regions with high levels of efficiency are all the Portuguese regions, Alentejo, Algarve, Central Region and Northern Region. All these regions have a level of efficiency of above $90 \%$. Other regions also have near optimum levels of efficiency, Wales R. V., Yorkshire and Humber, Cornwall I. S., Kriti and Valencia. The study also shows that there are numerous group of regions with efficiency coefficient near to 88\%, Brandernburg, Mecklenbourg-Vorpormmern, Sachsen, Sachsen-Anhalt, Thüringen, Burgenland, Andalucia, I. Canarias., Castilla-La Mancha, Murcia, Pohjois Soumi, Stelä Soumi, Anatoliki Makedonia T, Border, Midland et W., Puglia and Merseyside. 
The results show that the regions of Portugal and United Kingdom, despite being not efficient have a high level of efficiency, 90\%. The regions of Germany, Austria, Finland and Ireland have an efficiency coefficient of nearly $87 \%$. However, the rest of the countries have a lot of differences between the levels of efficiency of their regions. This situation is very significant in Spain, where there are regions with efficiency coefficient near to $90 \%$, the case of Valencia, and other regions like Extremadura with the lowest level of efficiency of the all Objective 1 regions. Therefore, this situation shows that these regions with a good economic situation administer the Structural Funds more efficiently. Spain is a good example of this case; the Spanish regions with high level of economic development have a higher efficiency coefficient than the Spanish regions less economic development.

All these results indicate that the Objective 1 regions have to improve the management of received Structural Funds to increase the level of efficiency and the results in their rate of employment and productivity.

\section{(Insert Table 11)}

\subsubsection{Comparative analysis of the measures of efficiency on the basis of different factors}

This section looks at whether the influence of certain characteristics of the regions determines different behaviours in terms of measures of efficiency. It takes as reference the studies by Raymon and García (1994), García-Milá and Marimón (1999) Martín and Tyler (2006). The following categorized variables are considered: country, group of the European Union and contribution of agriculture to the GDP of the region.

\section{Effect of country}

Table 12 offers the results of the estimations of parameters of mean of population, minimum and maximum of the measure of efficiency in the DMUs of the population of the regions define from country of origin. The analyse shows the case of France (Lille Reunion) which obtains a technical efficiency coefficient which is more than twenty points below the mean for the regions of Portugal and over eighteen points below that of the UK regions. This situation may be due to the special characteristics of that French region. It is an overseas region with a different level of economic development from other French regions. Spain stands out for the greater dispersion in the technical efficiency measurements (6.03), more than eight times that of the UK and more than five times that of Portugal. The cause for this high dispersion lies in the region of Extremadura whose efficiency coefficient is $39.52 \%$, which implies a technical inefficiency in Funds management of over 60\%.

When ANOVA is applied to control for the existence of significant differences between the mean values of the subpopulations, a p-value of 0.092 is obtained, implying that the hypothesis of equal values will be rejected for any level of significance, $\alpha$, higher than that value and, therefore, the existence of significant differences. These findings coincide with those reported by Beugelsdijk and Eijffinger (2005) and Crespo-Cuaresma et al. (2001). Nevertheless, the economic situation of the countries to which the regions belong does not affect their levels of efficiency since Portuguese regions are more efficient than German or Spanish regions, although Portugal has a lower level of economic development than both these. Thus, the difference is produced by the level of development of the regions analysed. In countries with similar levels of economic development among the regions analysed there is a higher level of efficiency than in countries with regions with different levels. 
(Insert Table 12)

At the same time $\left(100-\mathrm{ET}_{\mathrm{i}}\right)$ represents the percentage in which the production of a region could be increased without needing to increase the Funds employed. Estimations on inefficiency distributions are given in Table 13. The results show the need for better of management and control of the Structural Funds, since the results could be significantly improved from the application of these at the level of employment and productivity in the regions analysed. This situation has been one of the reasons which have led European authorities to modify the normative relating to control and management of the Funds for the period 2007-2013.

\section{(Insert Table 13)}

\section{Effect of geographical location}

Table 14 shows the estimations for the mean population parameters, the minimum and maximum of the DMU efficiency means in the subpopulations of regions defined according to the condition geographical situation: Northern Europe and Southern Europe.

\section{(Insert Table 14)}

When the means equality hypothesis is contrasted, a p-value equal to 0.081 is obtained for both groups, which implies that for any level of significance above 0.081 the hypothesis is rejected and, in consequence, it is admitted that there are significant differences between the groups of regions. As can be seen in table 14, the regions classified under Northern Europe score more than five points more in the mean levels of efficiency. Therefore, regions located in countries classified as belonging to Northern Europe are more efficient than those in the south of Europe. Delgado and Álvarez (2005) reported the same results in their study. The results show that countries in the north manage and apply the Funds they receive better, even though they receive lower amounts of resources than the countries in the south. Thus, countries which receive more resources are less efficient in managing them. Regions from the southern countries also tend to be less economically developed and are seriously lacking in infrastructures and other factors affecting economic growth.

\section{Effect of the Contribution of Agriculture}

Since the existence of a significant correlation between the measures of technical efficiency and the percentage of the regional contribution to the GDP, regions have been classified into two groups - those in which agriculture contributes up to $4.3 \%$ to the regional GDP and those in which the figure is higher (median of the distribution of the variable "Contribution of Agriculture to regional GDP").

Table 15 shows the estimations of the subpopulation mean, maximum and minimum efficiency measures of the DMUs in the subpopulations of the regions.

\section{(Insert Table 15)}

When checking the hypothesis for equality of means in both groups, a p-value of 0.074 is obtained, which implies that for any level of significance above this the hypothesis will be rejected and, therefore, there are significant differences between the groups of regions. As can be seen in Table 15, the regions where agriculture supposes a higher percentage are 5\% more inefficient in managing the European Funds. These results are in agreement with those reported by Maudos et al. (2000b) and Delgado and Álvarez (2003) in their study on Spanish regions. The results show how regions with less economic growth are those which use the Funds less efficiently. 
Finally, it should be pointed out that when applying the Battese and Coelli model (1995) other explanatory variables, $\mathrm{z}_{\mathrm{i}}$, have been tried out but we have found no other with a significant effect. One aim of the authors is to go more deeply into this analysis by including environment variables, other sociopolitical characteristics and, to the extent possible, the temporal component.

\subsection{Analysis of results}

DEA and Stochastic Frontier methodologies show differences in the level of efficiency of each region. Firstly, the Stochastic Frontier does not find efficient regions; meanwhile, DEA methodology has found eight efficient regions. Furthermore, DEA and Stochastic Frontier yield different efficiency distributions and rankings for Objective 1 regions. Puig-Junoy (2001) obtained the same conclusion for USA states. The justification of the different results obtained with DEA and Stochastic Frontier in the fact that efficient frontier, with DEA, is defined by a relatively small number of very efficient best practice regional governments, but with Stochastic Frontier the efficient frontier is determined with specific functional form using advances econometric techniques. Puig-Junoy (2001) determined that the methodologies have an impact of the level of efficiency of the analysed units.

The analysis of the influence of effect of country on the efficiency of Objective 1 regions shows different result using DEA or Stochastic Frontier methodology. Portuguese regions are the most efficient with DEA methodology, but, when using Stochastic Frontier regions of United Kingdom are more efficient than the Portuguese regions. The efficiency of the regions obtain using DEA is greater than the efficiency calculates applying Stochastic Frontier. These results show the differences between DEA and Stochastic Frontier methodologies.

The efficiency of Objective 1 regions considers the geographical location and Cont-Agric-GDP of the regions shows the same result applying the two methodologies. The regions coded as northern European are more efficient than those in southern Europe and the regions with Cont-Agric-GDP is lower are more efficient than the regions with Cont-Agric-GDP is higher. Furthermore, the level of efficiency calculated with DEA is higher than the level of efficiency obtained with Stochastic Frontier. This result is in line with previous results of our study.

The two methodologies, DEA and Stochastic Frontier, show similar results, the Objective 1 regions have to improve the management of the Structural Funds to increase the productivity and employment.

\section{CONCLUSIONS}

We have analysed the pure and global technical efficiency of Objective 1 regions over the financing period 2000-2006 in applying the Structural Funds received (excluding the FIFG) using rate of employment and productivity as outputs and parametric (Stochastic Frontier) and no-parametric (DEA) methodologies.

We have also studied the efficiency and determined variables like the country which the regions belong, the geographical situation of that country and the contribution of agriculture to the economies of the regions analysed.

This procedure of analysis has allowed us to come to the next results:

- Applying DEA, the rate of employment correlates significantly with efficiency, especially with pure technical efficiency $(82.1 \%)$. However, productivity rate does not correlate with efficiency applying DEA. Of the 46 regions studied only eight operate on the SE optimal scale. If we 
consider pure technical efficiency, PTE, thirteen regions operate efficiently regardless of the scale of operations.

- Using Stochastic Frontier, The hypothesis that each region operates at the frontier of technical efficiency is rejected, which indicates than inefficiency is present in the production function and the halfnormal distribution is accepted as valid. The estimation of the frontier function has enabled us to determine the existence of complementariness relations between ERDF funds and the combination of ESF and EAGGF funds. Of the 46 regions studied none operates at an optimal level of technical efficiency, although, we can point to certain regions which show a near optimal degree of technical efficiency.

- The study to determine, with DEA and Stochastic Frontier, relation between efficiency and certain variables reveals that the country to which the regions belong has no significantly influences on the efficiency. The other variable, geographical location (whether the regions analysed belong to a country in the north or south of Europe) shows differences in efficiency with regions in northern countries being more efficient than those in southern ones using DEA and Stochastic Frontier. Finally, we have classified the regions studied according to the contribution of agriculture to their GDP, and a higher level of efficiency for the group of regions in which agriculture accounts for a lower percentage applying the two methodologies.

These results show using parametric and no-parametric techniques that the Objective 1 regions may obtain better rate of employment and productivity with the received resources. Therefore, the regions have to improve the management of Structural Funds. The have to increase the control in the selection and execution of the project that they finance with Structural Funds.

The efficiency of the regions does not depend on the level of economic development of the country to which they belong, therefore, the efficiency of the regions depends on the other economic factors and the measures adopt by the regional authorities. Furthermore, the study shows that the regions of the northern countries that received fewer resources are more efficient than the regions of southern countries. Therefore, a high level of received Structural Funds implies less efficiency in the management of Structural Funds. This conclusion coincides with the result from analyzing the efficiency of the regions according to the contribution of agriculture to their GDP. These regions received less Structural Funds and they administer these resources better.

The European authorities have adopted different regulations to increase control and efficiency in the management of the Structural Funds.

In future research we intend to determine how efficiency in the application of these Funds varies for the period 2007-2013, considering the entry of new countries and the modifications introduced by European authorities in the norms regulating the Structural Funds.

\section{REFERENCES}

Afonso, A., Schuknecht, L. and Tanzi, V. (2010) "Public sector efficiency: evidence for new member states and emerging markets". Applied Economics, 42, 17, 2147-2164

Aiger, D., Lovell, C.A.K. and Schmidt, P. (1977) "Formulation and Estimation of Stochastic Frontier Production Models", Journal of Econometrics, 6, 21-37

Anh, T., Arnold, V., Charnes, A, and Cooper, W. W. (1989) "DEA and Ratio efficiency analysis for public institutions of higher learning in Texas", Research in Governmental and Nonprofit Accounting, 5: 65-185. 
Armstrong, H. W. and Wells, P. (2006) "Evaluating the governance of structural funds programmes: The case of community economic development in South Yorkshire”. European Planning Studies, 14, 6, 855-876

Balaguer, M. T., Prior, D. and Tortosa, E. (2007) "On the determinants of local governments performance: a two-stage nonparametric approach", European Economic Review, 51, 425-51

Banker, R. D., Charnes, A. and Cooper, W. W. (1984). "Some Models for Estimating Technical and Scale Inefficiencies in Data Envelopment Analysis”. Management Science, 30, 1078-1092

Battese, G. E. and Coelli, T. J. (1992). Frontier Production Functions, Technical Efficiency and Panel Data: With Application to Paddy Farmers in India. Journal of Productivity Analysis, 3, 153-169.

Battese, G. E. and Coelli, T. J. (1995). "A model for technical inefficiency effects in a stochastic frontier production function for panel data", Empirical economics, 20, 325-332.

Bauer P. W, Berger A. N, Ferrier G. D. and Humphrey D. B. (1998) "Consistency conditions for regulatory analysis of financial institutions: A comparison of frontier efficiency methods". Journal of Economic and Business, 50. 85-114.

Benito, B., Bastida. F. and García, J. A. (2010) "Explaining defferences in efficiency: an application to Spanish Municipalities". Applied Economics, 42, 5, 515-528.

Beugelsdijk, M. and Eijffinger, S. (2005) "The effectiveness of Structural Policy in the European Union: An empirical Analysis for the EU-15 in 1995-2001". Journal of Common Markets Studies, 43, 1, $37-51$

Beutel J. (2002) "The Economic Impact of Objective 1 Interventions for the Period 2000-2006". Report to the Directorate-General for Economic Policy Rsearch, London

Blackorby, C. and Russell, R. R. (1989) "Will the real elasticity of substitution please stand up? A comparison of the Allen/Uzawa and Morishima elasticities", American Economic Review, 49: 882-88.

Boland, P. (1999) "Contested multi-level governance: Merseyside and the European structural funds". European Planning Studies, 7, 7, 647-664

Boldrin, M. and Canova, F. (2001) "Inequality and Convergence: Reconsidering European Regional Policies". Economic Policy, 32, $202-253$

Bourguignon, F., Branson, H. and De Melo, J. (1992) "Adjustment and Income Distribution: A Micromacro Model for Counterfactual Analysis". Journal of Developments Economics, 38, 17-39

Bradley, J. (1997) Aggregate and Regional Impact: The case of Greece, Spain, Ireland and Portugal. Office of the Official Publications of the European Communities, Luxembourg.

Canova, F. y A. Marcet (1995) "The poor stay poor: non-convergence across countries and regions", CEPR Discussion Paper ${ }^{\circ}$ 1265 .

Cantos, P., Gumbau, M. and Maudos, J. (2005) Transport infrastructures spillovers effects and regional growth: evidence of the Spanish case, Transport Reviews, 25, 1, pp. 25-50

Cappelen, A., Castellacci, F., Fagerberg, J and Verspagen, B. (2003) "The impact of EU Regional support on growth and convergence in the European Union”. Journal of Common Market Studies, 41, 4, 621

Charnes, A., Cooper, W. W. and Rhodes, E. (1978). "Measuring the efficiency of decision making units". European Journal of Operational Research, 2, 429-444.

Charnes, A., Cooper, W. W. and Rhodes, E. (1981). "Evaluating program and managerial efficiency: An application of data envelopment analysis to program follow through". Management Science, 27, 668-697.

Christodoulakis, N. M. and Kalyvitis, S. C. (1998) "Achieving convergence within the European Union: The role of structural funds in the case of Greece". European Planning Studies, 6, 6, 695-707

Churski, P. (2008) "Structural Funds of the European Union in Poland-Experience of the First Period of Membership". European Planning Studies, 16, 4, 579-607

Coelli, T.J. (1996) “A Guide to DEAP version 2.1: A Data Envelopment Analysis (Computer) Program, Centre of Efficiency and Productivity Analysis”, University of New England Australia

Coelli T.J., Prasada Rao, D. S. and Battese G.E. (1998). An Introduction to Efficiency and Productivity Analysis. Kluwer Academic Publishers.

Crespo-Cuaresma, J., Dimitz, M.A. and Ritzberger-Grünwald, D. (2001) "Growth, convergence and EU membership. Österreichische Nationalbank", presented at East-West Conference November

Dall'erba, S. and Le Gallo, J. (2007) "The impact of EU Regional Support on Growth and employment". Finance a Uver, 57, 7-8, $325-340$ 
Dall'erba, S. and Le Gallo, J. (2008) "Regional convergence and the impact of European structural funds over 1989-1999: A spatial econometric analysis". Papers in Regional Science, 87, 219-244

Davison, A. C. and Hinckley, D.V. (1997). Bootstrap methods and their application. Cambridge University Press

Delgado, M.J. and Álvarez, I. (2003) “Comparación de la eficiencia técnica de los sectores productivos regionales: 1980-1995”. Documento de trabajo ICAE, n 25

Delgado, M.J. and Álvarez, I. (2005) "Evaluación de la eficiencia técnica en los países miembros de la Unión Europea”. Gestión y Política Pública,. 14, 1, 107-128

Domazlicky, B. R. and Weber, W. L. (1997) “TPF in the contigous United States 1977-86”, Journal of Regional Science, 37, 213-33 Dornbusch, R. (2000). “Ampliación Europea”, El País, Suplemento de Economía, 9 de julio

Efron, B (1979). "Bootstrap Methods: Another Look at the Jackknife". The Annals of Statistics, 7 (1), 1-26.

Efron, B., and Tibshirani, R. J. (1993) An introduction to the bootstrap, Chapman and Hall, New York

Esposti, R. and Bussoletti, S. (2008) "Impact of Objective 1 Funds on Regional Growth Convergence in the European Union: A panel-data Approach". Regional Studies, 42, 2, 159-173

EUROSTAT. Regional and Urban Statistics (2006). (http://epp.eurostat.ec.europa.eu/portal/page)

European Commission (1997) QUEST II. “A Multi-Country Business Cycle and Growth Model”. Economic Papers, 123, October European Comission COM (2004). Third progress report on cohesion: Towards a new partnership for growth, jobs and cohesion European Commission (2006). Regional Policy-Inforegio. (htt://europa.eu./regional_policy/projects/stories/index_en.cfm) Ederveen S., De Groot H., Nahuis R (2006) "Fertile soil for structural funds? A panel data analysis of the conditional effectiveness of European cohesion policy". Kyklos 59(1):17-42

Färe, R., S. Grosskopf, M. Norris and Z. Zhang (1994): "Productivity growth, technical progress and efficiency change in Industrialized Countries", American Economic Review, 84 (1), 66-83.

Farrell, M. J. (1957). “The Measurement of Productive Efficiency”. Journal of the Royal Statistical Society, Series (A), 120 (III), 253-281

Ferrier, G. D., and Lovell, C. A. K. (1990), "Measuring Cost Efficiency in Banking: Econometric and Linear Programming Evidence", Journal of Econometrics, 46: 229-45.

Forsund. F.R. (1999) "The evolution of DEA-The economic perspective. Sixth European Workshop on Efficiency and Productivity Anaslysis", Copenhagen

García-Mila, T. and Marimón, R. (1999) “Crecimiento de las regiones españolas”. Papeles de economía española, 80, 29-50

Gardiner, B, Martin, R. and Tyler, P. (2005) "Regional dimensions of Europe's growth problem: some brief reflections on the Sapir Report”. Regional Studies, 39, 979-986

Grabbe, H. and Hughes, K. (1998) "Reform of the structural funds: Central and East European perspectives". European Planning Studies, 6, 6, 665-676

Greene, W. W. (1990) “A Gamma- Distributes Stochastic Frontier Model”, Journal of Econometrics, 46, 141-163

Green, W. W. (1993) “The Econometric Approach to Efficiency Analysis”, The Measurement of Productive Efficiency, 2, 68-119

Gripaos, P., Bishop, P., Hart, T. and Mcvittie, E. (2008) "Analysing the impact of objective 1 funding in Europe: a review". Environment and Planning C: Government and Policy, 26, 499-524

Gumbau, M. (2000) "Efficiency and technical progress: sources of convergence in the Spanish regions", Applied Economics, 32, 467-478

Gumbau, M. and Maudos J. (2002) "The determinants of efficiency: The case of Spanish industry”, Applied Economics, 34, 19411948

Gumbau, M. and Maudos J. (2006) "Technological activity and productivity in the Spanish regions", Annals of Regional Sciencie, 40

Jondrow, J., Lovell, C., Knox, A. Materov, I. S. and Schmidt, P. (1982). "On the estimation of technical inefficiency in the stochastic frontier production function model", Journal of Econometrics, 19, 233-238

Jouve, B. and Negrier, E. (1998) "Multi-level governance 'French Style'? The contribution of the Europeqan Structural Funds to redefining intergovernmental relations in France”. European Planning Studies, 6, 5, 555-572

Kempkes, G and Pohl, C. (2010) "The efficiecy of German universities-some evidence from no parametric and parametric methods". Applied Economics, 42,16, 2063-2079

Kopp, R. J. (1981). “The Measurement of Productive Efficiency: A Reconsideration,” The Quarterly Journal of Economics, 96(3), 477-503

Krugman, P. and Obstfeld, M. (1997). International Economics: Theory and Policy. Addison-Wesley. 
Kutan, A. and Yigit, T. (2007) "European integration, productivity growth and real convergence". European Economic Review, vol. $51,6,13-70$

Lima, M. C. and Cardenete, M.A. (2008) “The impact of European Structural Funds in the South of Spain”. European Planning Studies, 16, 10, 1445-1457

Lovell, C. A. K. and Wood, L. L., (1992) "Monitoring the performance of Soviet Cotton refining enterprises: Sensitivity of findings to estimation techniques", Atlantic Economic Journal, 20: 25-31.

María-Dolores, R. and García Solanes, J. (2001). “Convergencia Real en Regiones Españolas: Un Análisis del Impacto de los Fondos Estructurales", Cátedra Jean Monnet, Working Paper 1-2001.

Martin, R. and Tyler, P. (2006) "Evaluating the Impact of the Structural Funds on Objective 1 Regions: An Exploratory Discussion”. Regional Studies, 40, 2, 201-210

Maudos, J., Mas, M., Peréz, F. and Uriel, E. (1998) "Public Capital, Productive Efficiency and Convergence 1964-93". Review of Income and Wealth, 44, 3, 383-396

Maudos, J., Pastor, J. M. and Serrano, L. (1999). Economic Integration, Efficiency and Economic Growth: The European Union Experience. Applied Economics Letters, 6(6), p.p. 389-92

Maudos, J., Pastor, J. M. and Serrano, L. (2000a) "Convergence in OCEDE Countries: technical change, efficiency and productivity". Applied Economics Letters, 6, 6, 757-765

Maudos, J., J., Pastor, J. M. and Serrano, L. (2000b) "Efficiency and productive specialisation: an application to the Spanish Regions". Regional Studies, 34, 9, 829-842

Maudos, J., Pastor, J. M. and Serrano, L. (2000c). "Crecimiento de la productividad y su descomposición en progreso técnico y cambio de eficiencia: una aplicación regional y sectorial en España (1964-1993)”, Investigaciones económicas, XXIV (1), 177-205

Maudos J., J.M. Pastor and Serrano L. (2003) "Human Capital in OECD Countries: Technical change, efficiency and productivity, International", Review of Applied Economics, 17,4, pp.420-435.

Maudos, J. and Gumbau-Albert, M. (2006) "Technological activity and productivity in the Spanish Regions". The Annals of Regional Science, 40, 1, 55-80

Meeusen, W. and Van Den Broeck, J. (1977) "Efficiency estimation from Cobb-Douglas Production Functions with composed Error", International Economic Review, 18, 435-444

Moore, B. and Rhodes, J. (1973). "Evaluating the effects of British regional economic policy”. Economic Journal, 83, 87-110

Musyck, B. and Reid, A. (2007) "Innovation and Regional Development, Do European Structural Funds make a Difference?". European Planning Studies, 15, 7, 961-983

Nolan, J. F., Ritchie, P. C. and Rowcroft, J. R. (2001) "Measuring the efficiency in the public sector using no parametric frontier estimator: as study of transit agencies in the USA". Applied Economics, 33, 7, 913-922

Pastor, J. M. (1995) "Eficiencia, Cambio Productivo y Cambio Técnico en los Bancos y Cajas de Ahorros Españolas: Un Análisis Frontera no Paramétrico", Revista Española de Economía, 12,1, 35-73

Pedraja, F. y Salinas, J. (1995). La eficiencia en la administración de justicia. Las salas de lo contencioso de los tribunales superiores de justicia. Revista de Economía Aplicada, 3, 8, 163-95.

Pedraja, F., Ramayo, J. and Salinas, J. (1999) "Eficiencia productiva del sector industrial español: un análisis espacial y sectorial". Papeles de Economía Española, 80, 51-67

Picazo-Tadeo, A. and Prior. D. (2009) Environmental externalities and efficiency measurement. Journal of Environmental Management, 1, 1-8

Prior, D. (1990) "La Productividad industrial de las Comunidades Autónomas”. Investigaciones Económicas, 14, 2, 257-267

Prior, D., Balaguer, M. T. and Vela, J. M. (2002) "Efficiency and Quality in Local Government. The case of Spanish Local Authorities", Documents de Treball (Universitat Atónoma de Barcelona),

Puigcerver, M.C. (2007) "The impact of Structural Funds Policy on European Regions Growth. A theoretical and Empirical Approach". The European Journal of Comparative Economics, 4, 2, 179-208

Puig-Junoy, J. (2001) “Technical inefficiency and public capital in USA States: A stochastic frontier approach", Journal of Regional Sciencie, 41, 75-95

Quindós, M.P., Vicente, M.R. and Rubiera, F. (2003) "Las actividades de I+D en la Unión Europea: Un análisis de la eficiencia”. Estudios de Economía Aplicada, 23, 3, 607-620

Raymon, J.L. and García B. (1994) "Las disparidades en el PIBL per cápita entre Comunidades Autónomas, y la hipótesis de convergencia”. Papeles de Economía Española, 59, 1002-1037 
Rhodes, E. (1978) "Data envelopment analysis and related approaches for measuring the efficiency of decision making units with application to Program Follow Through", Doctoral Thesis. Pittsburgh Carnegie-Mellon University. School of Urban and Public Affairs

Richmond, J. (1974) "Estimating the Efficiency of Production”, International Economic Review, 15, 515-521

Rodriguez-Pose, A, and Fratesi, U. (2004) "Between development and social policies: The impact of European Structural Funds in Objective 1 Regions". Regional Studies, 38, 1, 97-113

Russell, R. R. (1985) "Measures of Technical Efficiency”, Journal of Economy Theory, 25 (1), 109-126

Salinas-Jiménez, M. M. (2003) "Technological change, efficiency gains and capital accumulations in labour productivity growth and convergence: an applications to Spanish regions". Applied Economics, 35, 17, 1839-1851

Scheel, H. (2000) Holger Sheel's Data Envelopment Analysis Page http://www.wiso. Unidortmund.de/Isfg/or/sheel/doordea.htm. Shang, J. and Sueyoshi, T. (1995) "An unified frame work for the selection of a flexible manufacturing system, European" Journal of Operational Research, 85. 295-315.

Simar, L. and Wilson, P. W. (2000). "A general methodology for bootstrapping in non-parametric frontier models", Journal of Applied Statistics, 27(6), 779-02

Stevenson, R. E. (1980) "Likelihood function for generalized stochastic frontier estimation”, Journal of Econometric, 13, 57-66

Thanassoulis, E. (2001) Introduction to the theory and application of data envelopment analysis. A Foundation Text with integrated software. Kluver Academic Publishers. Boston

Taskin, F. and Zaim, O. (1997) "Catching-up and innovation in high and low income countries". Economics Letters, 54, 93-100 Treyz, F. and Treyz, G. (2003) "Evaluating the Regional Economic Effects of Structural Funds Programmes Using the REMI Policy Insight”. Avaible at :http://europa.eu.int/comm/regional_policy/sources/docconf/budapeval/index_en.htm Varian, H. R. (1990) Goodness-of-fit in optimizing models. Journal of Econometrics, 46,1-2, 125-140

Yildirim, H. S. and Philippatos G. (2007) "Efficiency of Banks: Recent Evidence from the Transition Economies of Europe, 19932000”, European Journal of Finance, 13(2), 123-143.

Zhu, J. (2002) Quantitative Models for Performance Evaluation and Benchmarking: Data Envelopment Analysis with Spreadsheets and DEA Excel Solver, Kluwer Academic Publishers, Boston

Zieschang, K. D. (1984) “An extended Farrell efficiency measure”, Journal of Economy Theory, 33, 387-396 